THE MORPHOLOGI OF THE SOMATIC CHPOLOSONES IN IIITUM

By

Robert N. Stewart

Thesis subritted to the Faculty of the Gracuate School of the University of haryland in partial

fulfiliment of the requirements for the degree of Doctor of Philosophy 
UMI Number: DP71129

All rights reserved

INFORMATION TO ALL USERS

The quality of this reproduction is dependent upon the quality of the copy submitted.

In the unlikely event that the author did not send a complete manuscript and there are missing pages, these will be noted. Also, if material had to be removed, a note will indicate the deletion.

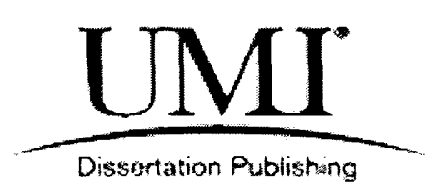

UMI DP71129

Published by ProQuest LLC (2015). Copyright in the Dissertation held by the Author.

Microform Edition (C) ProQuest LLC.

All rights reserved. This work is protected against

unauthorized copying under Title 17, United States Code

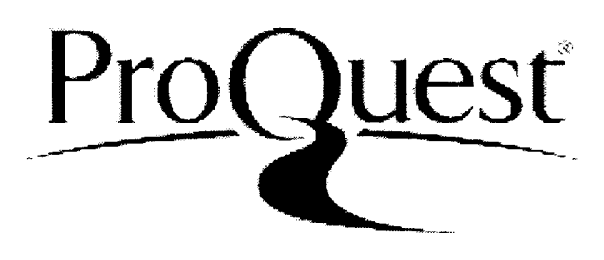

ProQuest LLC.

789 East Eisenhower Parkway

P.O. Box 1346

Ann Arbor, Ml $48106-1346$ 


\section{ACKNOW IEDOMENT}

The writer expresses his deep appreciation of the constant and valuable advice and criticiam of Dr. Ronald Bamford throughout the course of the work and the preparation of this thesis. 


\section{PABLE OP CONTEATS}

\section{Page}

InTropuction. ....................... 1 MATERTALS AND METHODS ................... 2 RESULES ............................ 5 prscussra.. ....................... 17 suMdaII ............................. 55 IITRRTURE CITED. ..................... 37 
INTRONUCTION

The cytogenetic literature is full of Instances where species relationships have been clarified by cytological evidence. In many plant groups, chromosome number has been shown to be the barrier separating species and information on chronosome number alone has solved these problems for the plant breeder and taxonomist. However, in other cases chromosome numbers have been found to be so widely variable that such knowledge alone merely serves to add confusion or the numbers are all the same and they furnish no new evidence. The geras filium has been investigated by numerous workers and all species are reported as having a sonatic number of twenty four (Sato, 1932: Sansome and IaCour, 1934; Bather, 1955; Beal, 1942 and Sterart, 1943) with the exceptions of the triploid species I. tigrinum (Takenaka and Nagamatsu, 1930) and several species in which aneuploids are found (Sansome and IaGour, 1934; Nather, 1955; Beal, 1942 and Stewart, 1943). A sinilar situation obtains in many other genera and in these cases useful information can be obtained from a comparative study of the chromosome morphology of the members of the group. Other cytogenetic methods available have been utilizod in the work recently reviewed on Crepis (Babcock et al, 1942; Babcock, and Jenkins, 1943; Babcock, 1944), Nicotiana (Goodspeed, 1945), and in the great mass of material on Zea and Drosophilla. It is recognized that the new systematics utilizes taxonony, norphology, cytology, genetics, physiology, ecology, paleobotany and all other divisions of plant science.

The earlier reports of chromosome number in Iilium were based on observations of sectioned material. The limitations of this method are obvious when dealing with chromosomes which are as meh as twenty eight microns in length at their nost contracted stage, above the optimum thickness of sections 
to obtain satisfactory staining and enable thorough examination. Cooper (1935-1936) utilized pollen grain divisions in L. Henryi and I. regale, but his illustrations show neither primary nor secondary constrictions. In recent investigations utilization of the propriono or aceto carmine smear technique and excised pretreatment with colchicine (stewart and Bamford, 1945; Ensweller and stewart, 1944) has given clear flat figures of the very long chromosones of Lilium and allow a critical study of their morphology. This is a report of such a study to serve as a base for more extensive investigations of the phylogeny of the genus and allow a moro efficient as well as a more frut tful breeding program.

\section{MATEFIALS AND METHODS}

Root tips were used exclusively for this atudy and these were taken from bulbs which were obtained from rellable comercial dealers in the United States. Those species native to this country were obtained from dealers specializing in native plants on both the east and west coasts. A few collections were made of native species and garden escapes in the vicinity of College Park. Few of the plants used in previcus studies (stewart and Banford, 1943; Stewart, 1943) survived the interval and plants reported here represent additional data on the occurrence of aneuploids in Iilium (stewart, 1943). This collection represents a large majority of the species, varieties and horticultural forms now available. Identification has been checked with the following sources: Wiwes (1880), Wilson (1925), woodcock and Goutts (1935), slate (1939), and various articles in the foyal Horticultural socioty Ifly Year Books.

Root tips were fixed in $3: 1$ absolute alcohol - glacial acetic acid for 
twenty four hours, then rinsed and stored in 60 percent alcohol until used. Smears were nade by the pnopriono-camine technique. The onission of acid hydrolysis and the use of glass tools throughout to eliminate any trace of iron in the stain resulted in the nucleoli staining a bright red color from twenty four to forty eight hours after the preparation of the slide. The roots prepared in this way showed cells at the critical stages of mitosis for the classification of constrictions as shown in plate 7.

The morphology of the chromosones at sonatic metaphase was detemined from divisions in root tips given excised pretreatment for thirty minutes in a .2 percent aqueous solution of colchicine followed by washing in water for ninety minutes. This is a slight modification of previous methods (Burre11, 1939; Omarra, 1939; stewart and Banford, 1943; Stewart, 1943; Emsweller and Stewart, 1944). Duds and mature pollen have been collected and preserved for future work.

Observations were made with the aid of $43 x$ and $90 x$ apochromatic oil immersion objectives and $15 x$ compensating oculars. Camera lucida dratsings at table level (approximately 2000x) were made of all the netaphase chromosomes separately in from one to three cells of each plant of a species or variety. These were cut out and for each cell arranged in pairs on the basis of total length, position of primary constriction, number and position of nucleolar secondary constrictions. The idiograms (Plates 8-13) are these drawings of a haploid set from a typical cell which was the least distorted in preparation and traced so that the primary constrictions appear on a horizontal line. The order left to right in each case is of increasing arm length ratio (long, short) rising from approximate unity. Ietters are assigned to the chromosomes according to thoir order in this schame. Both chromosomes of pairs which are heteromorphic in the position of the secondary constrictions are shown and designated by a letter and its prime. The centric 
fragments and extre chromosomes which are not duplications of one of the normal complement are placed on the right regardless of the length of its short arn and are designated by the letter $M$. In those cases where the heteromorphic pairs differ by a measurable amount of chromatin, they are also placed at the far right but given the letter of the position they would occupy in the Ldiogram assuming loss of material from the smaller member of the pair.

In addition to the camera lucida ldiograms a series of photoidiograms of representatives of the divisions of the genus Iilium; subgenus Cardiocrinum (I. Eiganteum) and the four sections of subgenus pulirion; Leucolirion (I. Brownit), Archelirion (I. duratum), Isolirion (I. concolor), and Martagon (I. monadelphum). These photoidiograms are constructed in exactly the same way as the other idiograms except that photonicrographs are used in place of cemera lucida drawings. Plates 2 and 3 are photomicrographs of somatic metaphases in roots of $I$. concolor and $L$. Brownil respectively from which enlargements were made to construct the photoidiograms.

Table 1 presents the percentage of the total length of all the chromosomes in the idiograms represented by each of the chromosomes. Pairs heterom morphic for secondary constrictions shown trice in the idiograms are figured only once in the table. For pairs hoteromorphic for a measurable amount of chromatin, the average is used. Plants having extra chromosomes are figured twice, with and without the extra chromosomes.

The idiograms thus constructed present an exact picture of the haploid set of chromosomes from a typical cell of the species. However, from an exanination of these idiograms alone, no conclusions as to the variation in size of karyotypes can be drawn. Thtre is no indication that the re is more chromatin in cells of any one species of Iilium than in any other. There is as great difference in cell and chromosome mass between adjacent cells in the 
aame root as between cells from different species. The idiograns, being camera Iucida drawings all at the same magnification, reflect only the latter variation. None of the gradual curves or spirals in the chromosomes shom are characteristic of the morphology of the chromosome. They represent only the chance result of all the forces of coiling, movement, and smearing pressure. However, the indentations or "incomplete" constrictions such as that in the short arm of the $C$ and $i$ cirromosomes of auratum, in the short arm of the $G$ chronosome of Eiganteum, and in many others are constant morphological details as characteristic and definite as any other feature.

\section{RESULTS}

The results are presented almost completely by the idiograms (P1ates 8 - 13). There are no large variations in chromosome morphology in the genus, all species having two long pairs of chromosomes with submedian centromeres and ten pairs with subteminal centromeres. The $2 n$ mamber of all species reported here is 24 and, although individuals were found in I. auratum, I. tsingtauense, I. Sargentiae, and L. panilum with $2 n=25$ and one plant in I lenry with $2 n-26$, the additional chromosomes are, with two exceptions, centric fragments and in all cases are unlike any of the normal complement. However, the variations in the length of the chromosomes and the variation in position and function of the constrictions differentiate the species into two groups.

The following is a detailed classification of the constrictions under each of the species and varieties observed. (PIates 8 - I8). 
L. concolor: Seven plants were axamined and the karyotype of five of these (type 1 in Table 1 ) is represented by the idiogran in figure 1. Both chromosomes of pairs A, B, F, I, and I were asscciated with nuclooli at their secondary constrictions in prophase. A maximu of ten macleoli were observed in resting cells. The constrictions in the short arms of pairs 0 and $D$ were non-meleolar. In the sixth plant the chromosomes were the same except that the secondary constriction in the I pair of chromosones was absent. The I pair was not associated ifth nucleoli at prophase and a maximum of eight nucleoli were observed in resting cells. The seventh plant (type 2 in tablo 1) differed from the first five in that the secondary constriction in one of the $B$ pair of chromo somes was nearer the end of the short arm (fig. 2 and photoidjogram plate 1.)

L. Bromiz: Three plant3 were examined and their karyotype is represented by the idiogram in figure 3 and the photoidiogram in Plate 1. The secondary constrictions in the chromosomes $D, F$, and $G$ wero nucleolar, having been observed attached to nucleoli in prophase. A maximum of six nucleoli were observed in resting cells. The constrictions in the short arms of chromosome pairs $\mathrm{C}$ and $\mathrm{E}$ were non-mucleolar.

I. candidum: Three plants were examined and their karyotype is represented by the jidiogram in figure 4. The I pair was heteromorptic for the secondary constriction in the short arm. The satellite was so small that it was impossible to determine whether or not it was present but it seemed probable that it was fused with the short arm of the I chromosome. Another irregularity was the presence of three $K$ chromosomes and only one $J$ chromosome. This is one of very few cases where a pair is 
hetercmorphic for a measurable amount of chronatin. The secondary constrictions in the $D$ and $F$ pairs, and the I chromosone are nucleolar. A maximum of five mcleoli were observed in resting cells. The secondary constrictions in $C$ and $\mathrm{S}$ were non-nueleolar.

\section{I. callosume (fig. 5) All five plants were alike having six pairs} with nucleolar secondary constrictions; $A, C, F, G$, and $I$ and also the distal constriction in short arm of the $B$ chromosomes. The proxinal secondary constriction in the short arm of the $B$ pair and the secondary constriction in the short arm of $D$ were non-racleolar.

L. Davldij (fig. 6) Three plants had four pairs of nucleolar secondary constrictions in chromosome pairs A, D, F, and G. The constriction in the short am of $C$ was non-nucleolar.

L. speciosum: The karyotypes of two plants of var. album, two of var. rubrum and four of var. magnificum proved to be identical and are represented by the idiogram in figure 7. The distal constriction in the short arm of $A$ and those in $C$, $E$, and $I$ were nucleolar. The prosimal constriction in the short arm of $A$ is non-nucleolar. Figure 8 represents the karyotype found in two plants of var. punctatum. It differs from the other three varieties only in the A pair of chromosomes there one secondary constriction in each was in the long arm and was nucleolar. The maximum nucloolar count in all varieties was eight.

I. monadelohum: (fig. 9 and Plate 1) The three plants al1 hed eleven nucleolar secondary constrictions; distal in the short arm of both of the $O$ pair, in both of the $D, E$, and $G$ pairs, one in the long arm of $F^{\prime}$ and two in the long arm of the $\mathrm{F}$ chronosome. The F chromosome was the 
only one observed in Ililum with two meloolar constrictions. In almost every prophase observed; both constrictions were associated with nucleoli. The proxinal constriction in the short arm of the $A$ and $C$ pairs were nonnucleolar. The length of the short arm of the $C$ pair was mach greater then that of any but the $A$ and $B$ pairs in any of the other species.

L. auration: In seven plants of this species that were exanined, three karyotypes were found (figs, 10, 11, 12). All were identical in the first ten pairs, A through J. The A, B, and D pairs had nueleolar secondary constrictions in their long arms and non-nucleolar secondary constrictions in their short arms. The $C$ pair had mucleolar secondary constrictions proximal and nop-nucleolar secondary constrictions distal in their short arms. The $E$ pair had non-mucleolar secondary constrictions in their short arms. Four plants (type $I$ in table I) are represented in figure 10 and Plate 1. The I pair had a nucleolar secondary constriction In the long arm and there was twenty fifth chromosome, or centric fragmont, designated M. One plant (type 2 in table I) is similar except thet it did not have the centric fragment (fig. 11). Two plants (type $z$ in table 1) were like type 2 except that there was a nucleolar secondary constriction in the long arm of both of the $\mathrm{K}$ pair in the same position as in the $L$ pair, from which they could not be distinguished (fig. 12 ). It is possible that the first two types are heteromorphic for secondary constrictions in the $K$ and $I$ pairs as no evidence of genetic or pairing homology has been obtained and, except for the secondaxy constrictions, the $\mathrm{K}$ and $\mathrm{I}$ pairs are indistinguishable.

I. gigantewn: (fig. 15 and Plate I). All three plants examined were alke having $B, C$, and $D$ pairs with nucleolar and $G$ with non-nucleolar secondary constrictions. 
L. tsingtauense: The two plants (type 1 in table 1 ) represented in figure 14 and the one plant (type 2 in table 1) represented in figure 15 were identical except for the chromosome $M$ which was an extra chronosome present only in the single plant. Both types had nucleolar secondary constrictions in the long arms of chromosome pairs $C, D, F$, and $J$ and non-nucleolar secondary constrictions in the short arm of pairs $C$ and $\mathrm{D}$.

L. Grayi: (fig. 16) The two plants examined were identical and had nucleolar secondary constrictions in the long arm of pairs $C$ and $K_{\text {md }}$ and non-nucleolar secondary constrictions in the short arm of $C$ and D.

L. Japonicum: (fig. 17) The two plants examined were alike with nucleolar secondary constrictions in pairs $B$, proximal in the short and of $\mathrm{D}$, and in L. There were non-nucleolar secondary constrictions in $A, C$, distal in the short arm of $D$, and in F.

L. Leichtlinit var. Laximowiczil: (fig. 18) Three plants exanined were alike, having nucleolar secondary constrictions in pairs $A, B$, and $G$ and a non-aucleolar secondary constriction in $C$.

I. Henryis Three plants were examined. Two had twenty four chromosomes (fig. 19 and type $I$ in table 1 ) and one had twenty four plus two centric fragments (fig. 20 and type 2 in table 1). Except for the fragnents they were alike. There were nucleolar secondary constrictions in the $A$ and $F$ pairs and non-nucleolar secondary constrictions in the $C$ pair.

I. 폭agon var. album: (fig. 2I) Three plants were all alike, having nucleolar secondary constrictions in $A, B$, long arm of $C, F$, and $K$. 
There were non-maleolar secondary constrictions in the short arms of the $C$ and $D$ pairs.

L. Longiflomp Creole, Estate, and Slocums Acet (fig. 22) Five plants of Creole, two of Estate, and three of Slocums Ace were alike, having nucleolar secondary constrictions in $\mathrm{D}, \mathrm{G}$, and the long arn of $\mathrm{C}$. $\mathrm{N}$. maleolar constrictions were present in the short arif of $C$ and $\mathrm{f}_{\text {. }}$

I. Lormosanum: (fig. 22) Three plants proved to be exactly like I. Longiflorum.

I. resale: (fig. 24) Seven plants examined were alike, having nucleolar secondary constrictions in the short ars of pairs $A$ and $C$, and in the long arms of $B, D$, and $E$. There were non-mucleolar secondary constrictions in the short arms of $B, D$, and $E_{0}$

L. Eyriophylixas (fig. 25) Two plants examined were exactly like I. regale.

L. Sargentiag (fig. 26 and type 1 in table 1) Three plants examinod were exactly like I. regale.

I. Sarkentiae Horsford: (fig. 27 and type 2 in table I) One plant available was exactly like the type and like I. regale but with one additional centric fragnent labellod $\mathrm{y}$ in the idiogram.

L. Ieucanthum var. chloraster: (fig. 28) Tree plants examined were exactly like I. regale.

L. dauricum: (fig. 29) Four plants of L. dauricum were alike. There mere nucleolar secondary constrictions in the $A, B$, and $G$ pairs and non- 
nucleolar secondary constrictions in the short arm of the $C$ pair. The secondary constrictions in the long arrss of both the $c$ and pairs behaved in the same way. At metaphase the constriction always appeared in one and ocassionally in both chromosomes of a pair. In a smaller number of observations of prophase cells, one chromosone of each was usually associated with a nucleolus, but never both chromosomes of either pair. It was impossible to determine if it was always the same nember of the pair. The secondary constriction in the nember of each pair not associated with the nucleolus was usually visible in these prophase cells. A neximun of eight nucleoli were observed in resting cells. Trree plants of I. dauricum var. Eilsoni were examined and were identical with the typo except that the secondary constrictions in the long arms of the $G$ and pairs appeared very rarely and none were ever seen associated with nucleoli. in prophase. The maximum nucleolar count in the resting cells of the variety was six.

I. Duchartzei. (fig. 30) Two plants examined were alike, having nucleolar secondary constrictions distal in the short arn of the $B$ pair, and in the $C$ and $G$ peirs. There were non-nucleolar secondary constrictions proximal in the short arm of the $D$ pair.

I. 紫ardif: (fig. 31) Only one plant was available. There vere nucleolar secondary constrictions in the $A$ and $D$ pairs.

L. amabile: (fig. 32) Three plants of amblile and tro of var. luteum were all alike. There were nucleolar secondary constrictions in the $A$, $F$, and $G$ pairs and non-nucleolar secondary constrictions in $C$ and $D$. 
I. pusilum (figs. 33,34, and 35 ) Ten plants of L. pumilum (fiE. 35 and type $I$ in table 1 ) and six plants of I. pumilum Golden Gleam (IIS. 34 and type 2 in table I) were alike. A seventh plant, of Is pumilum Golden Glean (fig. 35 and type 3 in table I) had the same twelve pairs plus one extra chromosome labelled $y$ (fig. 35). All seventeen plants had mucleolar secondary constrictions in the $A, B, D$, and $F$ pairs and in the long axn of $C$. There were non-mucleolar secondary constrictions in the short arms of $C$ and $E$.

I. superbum: Two karyotypes were found in collections of L. superbum from vory mall area in swamp near college Park. Two plants are shown in figure 36 (type 1 in table 1 ) and five more from the collection and three plants from a comerclal dealer are show in figure 37 (type 2 in table 1 ). Type 1 had mucleolar secondary congtrictions in pairs $C, j$, and $K$ and non-nucleclar secondary constrictions in the short arn of $h$. Type 2 hed nucleolar secondary constrictions in the long arms of $C, D$, and $K$ and non-mcleolar secondary constrictions in the short arms of the $D$ pair. The two types were very similar in the distribution of chromatin (table 1) and the only difference is the position of one of the three pairs of secondary constrictions in each.

L. philadelobicum: (fig. 38) Three plants examined were alike, having nucleolar secondary constrictions in pairs D, F, K, and I, and nonnucleolar secondary constrictions in $C$.

I. Catospoei: (fig. 39) Only one plant was available. Letaphases were abundant and it wes possible to determine the position of the constrictions and fron anaphase figures it was possible to classify them as 
primary or secondary. However, there were many nucleoli and many chromoscmes attached to them in prophase and the nucleolar activity of some of the constrictions could not be determined. Both secondary constrictions in $B, C, K, L$, and the distal ones in the long arm of the $F$ pair were all identified in prophase as associated with mucleoli. In those prom phases where the distal constriction in the long arm of an F chromosone was seen associated with a nucleolus it was deterwined that the proximal constriction was not and it is probable that it is non-nucleolar. At least two and probably all four of the secondary constrictions in the $D$ and $E$ pairs were nucleolar, but no clear cut case of association of all four was found.

I. carolinianums (ILg. 40) Four plants examined were alike, having nucleolar secondary constrictions in the $f$ and $L$ pairs and non-macleolar secondary constrictions in the $G, E$, and $G$ pairs.

L. michiganense: (fig. 4I) Five plants were alike, having nucleolar secondary constrictions in chromosome pairs $\mathrm{E}$ and $\mathrm{G}$ and non-nucleolar secondary congterietions in $C$ and $D$.

I. canadense: (fig. 42) Five plants of I. canadense, two of I. canadense var. rubrua and two of I. canadense var. flanum all possessed identical karyotypes and all were indistinguishable from I. michiganense.

L. pardalinum var. giganteum: (fig. 43) Three plants examined had identical karyotypes. There were moleolar secondary constrictions in the long arms of pairs $H, I$, and $K$ and non-jucleolar secondary constrictions in the short arms of $C$ and $D$ and in the long arms of $C$ and I. The F pair is hetermorphic for a neasurable amount of chromatin. They are 
lottered $F$, and loss of material from $F$, presumed, because they differ only in that way from the species type and the other Vestern North American species to whick this varioty is obvicusly closely related.

L. Roeziil: (fig. 44) Two plants were examined and were alike, having nucleolar secondary constrictions in the long arms of pairs $H, I$, and $K$ and non-nucleolar secondary constrictions in the short arms of $C$ and $D$ and in the long arms of $\mathrm{C}$ and $\mathrm{L}$. The karyotype appears identical to that of Io pardalinum var. giganteum except for the $F$ ' chronosome.

L. pardalinum: (fig. 45) Three plants were examined and were found to have karyotypes identical with that of I. Roezlii.

L. Parryi: (fig. 46) Mree plants were found to have identical karyotypes and $\mathrm{alI}$ were similar to that of L. Ploezlif except that the long arm of the $\mathrm{A}$ pair of chromosomes is measurably shorter.

L. occidentale: (fig. 47) Two plants were found to have identical karyotypes. The pair was heterozygous for a nucleolar secondary constriction in the short arm and there were also nucleolar secordary constrictions in the Ion $E$ arms of pairs $\mathrm{H}, \mathrm{I}, \mathrm{K}$, and I. There were non-nucleolar secondary constrictions in the short armo of $C$ and $D$ and in the 105, ann of c.

L. columbiamm: (fig. 48) Three plants were found to have identical karyotypes similar to that of $\mathrm{L}$ occidentale except that the B pair of chromosomes was homozygous for the nucleolar secondary constriction in the short arn. 
PABLE I

Percentage of chronosono longtil to total length in idiograns

SRECI SS

goncolor (1)........... 12.1

concolor $(2) \ldots \ldots . . . . .12 .1$

Brownil . . . . . . . 12.8

candidum. .......... 11.0

callosum. . . . . . . . . 11.9

DavidiI........ 12.6

speciosum vars. album, mubrum,.

masnificum . . . . . 12.8 gpeciosun var. punctatum. . . . 11.9 monedelohum ........ 11.8 auraturif (I) ......... 12.7 " $"$........ 18.0 auratum (2)........ 12.0 auratun (3)........ 12.3 giganteun ........ 13.7 tsingtauense $(1) . . . . . .12 .6$ tsingtauense (2)........ 12.6 $"$ "...... 12.0 Gravi ........... 11.6 japonicum ........ 12.1 Leichtlinti var hexinowiczij. . 12.9 Henryi (1). ........ 12.y Henryl (2)......... 12.7 " ".......... 12.9 martagon album. . . . . . 12.2 longiflorum hfs. Creole, hstate,.

Slocum's Ace . . . . . 12.4 formosanum. . . . . . . 12.8 regalo. . . . . . . . 12.9 myriophylium. . . . . . . 11.9 Sargentiae horsford ...... 12.2 Sarcentiae. "...... 12.4

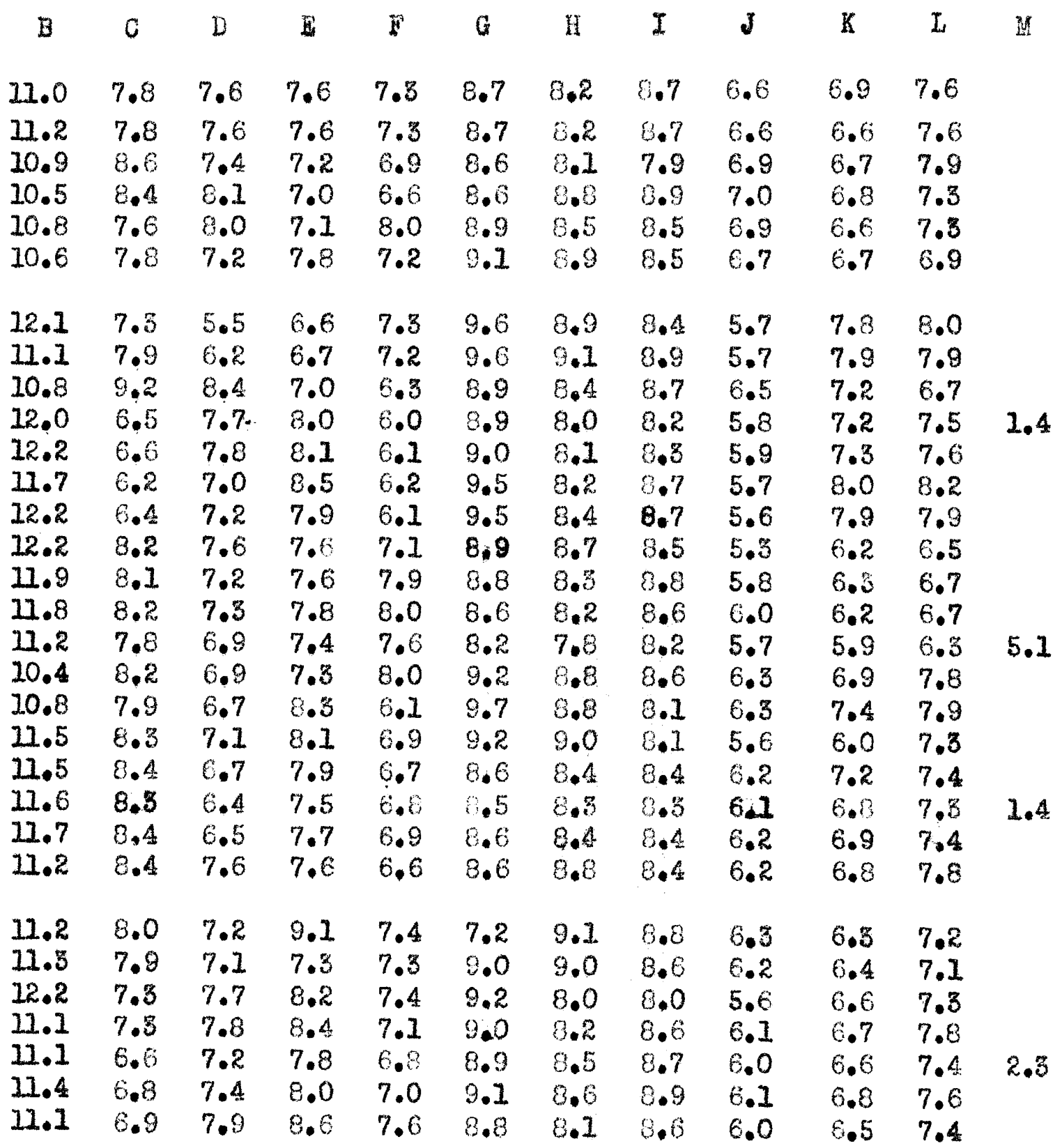




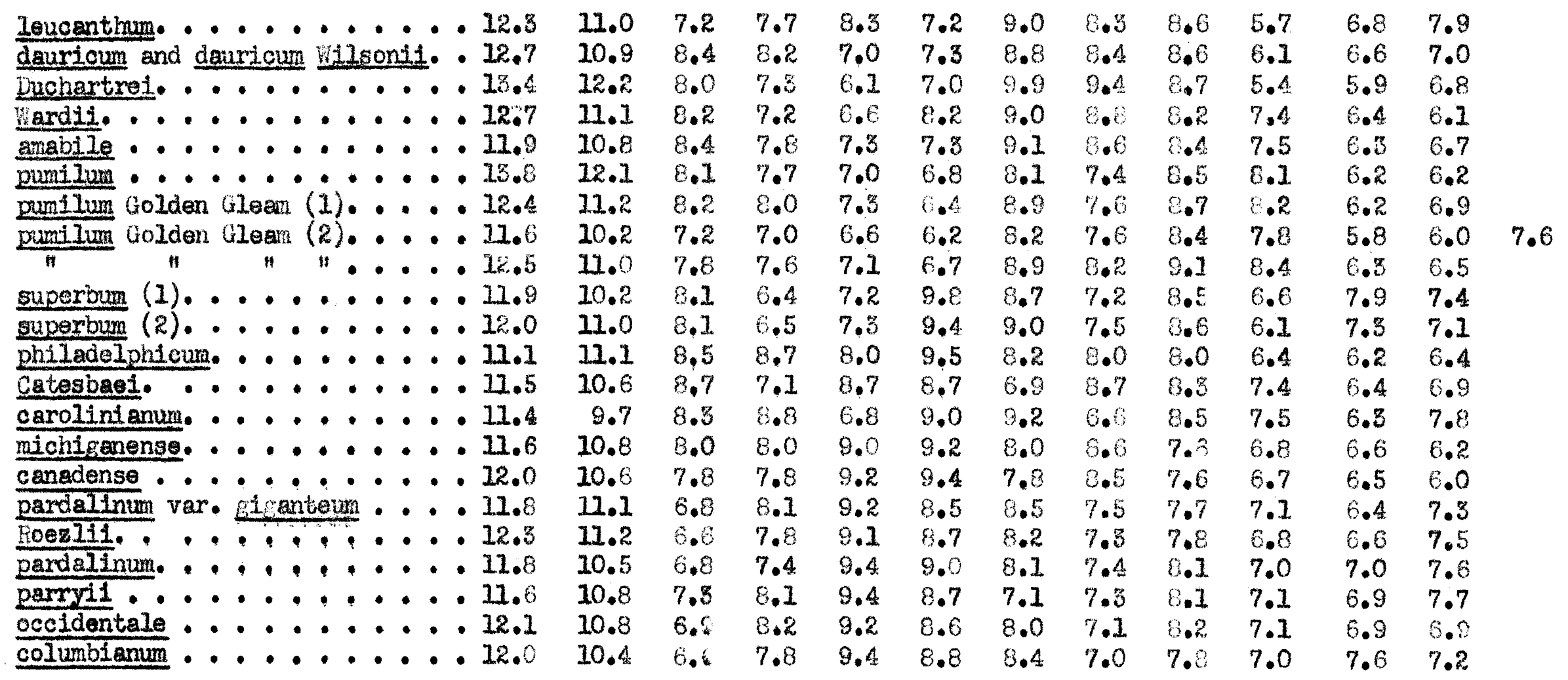




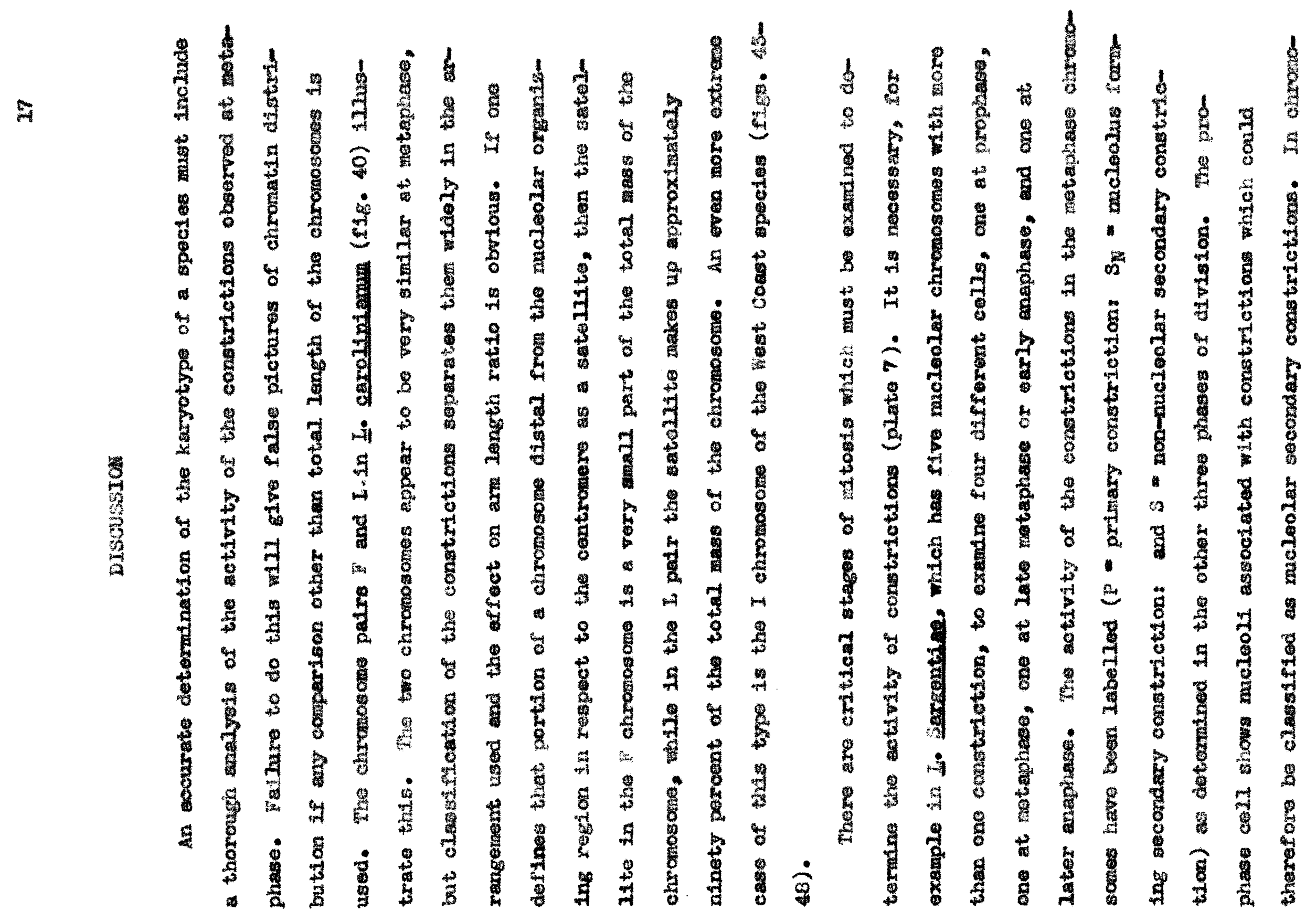


somes with only two constrictions, the other can be clessed as a primary constriction or centromere. The chromosome at prophase shows that the two constrictions wich are unassociated cannot be differentiated and additional evidence is necessary. In one particular cell, none of the three constrictions in either of the $D$ pair of chromosones was associated with a nucleolus. However, in approxinately eighty percent of the prophases examined, both chromosomes of the pair, and, in approximately eighteen percent of the cells, only one of the chromosomes of the pair were associated with nucleoli at the constriction classified as nucleolar. This failure of constrictions which are usually nucleolar to be associated with nucleoli (variation in meleolar activity between members of a par) is typical of all the nucleolar constrictions of which a large muber of observations were made. In this species the frequency of failure to associate with mucleoli in prophase was very Low in the nucleolar secondary constrictions of the A, B, and $C$ pairs and significantly higher in the $D$ and $B$ pairs. The variation in micleolar activity (botween pairs) is comon throughout the genus. The difference in the frequency of macleolar association of the secondary constrictions in the $C$ and $F$ pairs between I. dauricum and L. dauricum var. 留ilsoni was the only difference in their karyotypes. This indicates the need of examining large numbers of prophases. In this report, those secondary constrictions which were definitely associated with nucleoli in more than one of the prophases oxanined, wore classifiod as nucleolar. Those never associated with nucleoli were classified as nonnucleolar. From 15 to 20 prophases were analyzed in every species and as many as 30 in several.

The prinary constriction or centromere can be identified in late metaphase (plate 7). The chromosomes appear couble and at the very 
begiming of anaphase movement, the centromeres can be seen separating while the remainder of each chronosone, including the secondary constriction, has not separated.

At anaphase the centromere can be distinguished by its orientation towards the pole. The attenuation of the secondary constrictions as seen in chromosomes $A, B$, and $D$ is related to the mass of chromosome distal to the secondary constriction. Secondary constrictions in the short arms of the ten pairs of chromosomes with subterninal centromeres are never attenuated at anaphase while those in the long arms near the centromere are almost always attenusted $(H, I$, and $\mathrm{K}$ chronosones of the rest coast species, fig. $43-48$ ).

It is of interest to note, while examining the anaphase chromosomes, that it is not necessary to set an arbitrary arm length ratio to separate the I type and J type chromosomes in the karyotype. In chromosones with very short ams the short arm does not bend back during anaphase movement (the $K$ chromosome alongside the A chromosone and the I chromosone next to $\mathrm{E}$ in the anaphase in plate 7 ). The other chromosomes, G through J, which are not illustrated, also appear as I type chromosomes at anaphase. The short arms of chrorosomes A through f bend back during anaphase movement (anaphase in plate 7) and they appear as $y$ bype chromosomes.

All the chromosomes of a species can be identified in prophase and their nucleolar attachments determined. In the prophases of root cells which had not received colchicine pretreatment (plates 4 and 5 are a camera lucida drawing and photomicrograph respectively of an untreated prophase cell in I. callosum wnose idiogram is presented in $\mathrm{fig}$. 5), it is evident that the large numbers of secondary constrictions found in 
Filium are not artifacts resulting from the colchicine treatment used to obtain large numbers of metaphases. Confimation of the constrictions observed in colchicine treated metaphases was obtained in untreated netaphases in several species and in untreated prophases in all species. In I. callosum (plates 4 and 5), both chromosones of pairs $A, G$, and $K$ and one of pair are almost invariably attached to moleoli. However, in some prophases both of the $F$ pair, one or both of the $C$ pair, and one or both of the $B$ pair at the distal constriction in the short arri are also at tached to mucleoli. The proximal constriction in the short arm of the B pair is typical of the three cases of constrictions which always appear as full constrictions at metaphase but are never attached to maleoli. The indentation or "Incomplete" secondary constriction in the short arm of the D pair is typical of those of that type which are, with the except

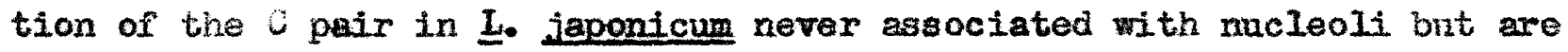
constant morphological features of the chromosome. I. callosum shows marked variation in frequency in the association of nucleolar secondary constrictions with nucleoli at prophase. The $f$ chromosomes display differences within a pair. Difference in irequency between pairs distinguishes the secondary constrictions of the A, $\vec{F}, G$, and $K$ pairs, which are associated with mucleoli in over ninety-five percent of the prophases from the secondary constriction in the $C$ pair and the distal secondary constriction in the $\mathrm{B}$ pair which are associated in approximately twenty-five percent of the prophases. These, in tum, are distinguished from the secondary constrictions proximal in the $B$ pair and in the $D$ pair which are never associated and are classified as non-nucleolar. It is probable that the frequent observation in resting cells of fewer nucleoli than nucleolar secondary constrictions is cue not only to fusion of nucleoli, but also 
to failure of nucleolar secondary constrictions to form nucleoll.

Variation in maleolar activity between a pair of nucleolar secondary constrictions is also found in I. Eiganteum (plate 6). The secondary constriction of one B chromosome illustrated is not associated with nucleoli in this particular cell. Hovever, it is associated in a Iarge percentage of the prophases observed and is therefore classified as nucleolar.

This data confirms the association of secondary constrictions and nucleoli reported by Heitz (1931), Fesende (1937), Sterart and Barford (1942), and the immumerable cases mentioned in Gates' review (1942). Previous reports of non-nucleolar secondary constrictions (Fernandes, 1936; Resende, 1937; Sato, 1938; Jacob, 1940; Stewart and Banford, 1943, etc.) are supplemented. However, the fajlure of nomaliy nucleolar secondary constrictions to be associated with nucleoli and the measurable variability of this feature has not been previously reported. Enough reports of non-maleolar secondary constrictions have found their way Into the literature to make it necessary to differentiate between secondary constrictions or satelite constrictions and the nucleolar attachment regions. Statements as to the correspondence of attachnent regions and nucleolar numbers are meaningless (Gates 1942). The maximum number of mucleoli in resting cells was deternined for all the species of Iilium reported, and was in all cases equal to the maximum number of chronosomes observed associated with mucleoli at secondary constrictions in prophases. In all but one species of Iilinm of over forty examined there were additional non-nucleolar secondary constrictions.

Van Camp (1924), Demen (1933), Woods (1937), and letsurra (1938) give reduction of number by fusion as the cause of the high frequency of 
less than the axinum number of nucleoli observed in resting calls. Fallure of nucleolar constrictions to form mucleoli mast be recognized as an additional factor.

Polyploidy as a source of variation in nucleolar number within a genus (Gates 1942) is rulad out in the howoploid genas lilium where, nevertheless, maximum nucleolar numbers of species varies from four te fourteen with several instances of odd numbers resulting from chromom sone pairs heteromorphic for secondary constrictions.

The order of the idiograms (plates $8-13$ ) is an at iempt to arrange the species on a basis of similarity of distribution of chromatin within the karyotype. Since the chromosones in each ldiogram are arranged fromil A to $L$ on a basis of the decreasing length of the short arms, the curve formed by connecting the ends of the successive long arms will indicate relative distribution of chromatin.

A11 species had two long pairs of chromosomes with submedian centrogeres, the $A$ and $B$ pairs. The small variations in length of these has been ignored in the arrangement of the species. In 311 the other chrmasomes of the regular complement of all species the centromeres subtermiral. The variation of distribution of chromatin amone these chromosomes is discontiruous on several levels and first allows separation into two groups. In Croupe 1, the $C, D, E$, and $F$ pairs are relatively short with low arm length ratios, the $O, H$, and $I$ pairs are long with high arm length ratios, and the $J, K$, and $L$ pairs short but still with high arm length ratios. This relative distribution is very definite in the spocies representea in figures 1 through 30 . The species represented in figures 31 through 35 differ only in that the increasing length of the $J$ chromosome 
moves it from the JIL class to the GHI class. Group 2 consists of the rest of the species examined (figs. $36-48$ ). In I. superbum (figs. 36 and 37) the CIEF class is reduced to three pairs and the GHI class is increased to hr. In I. philadelphicum the classes are only sligitly different but the species represented in figures 39 and 40 are markedy distinct from these and from each other. The karyotype of I. canadense (fig. 42) is identical with that of L. michiganense (fig. 4I). The variation is again stabilized in the remaining species (figs. $43-48$ ) and appears idertical except for the relative shortness of the G pair in I. Parryi (fis. 46$)$

Further subdivision based on veriation of chromatin distribution alone depends on smaller differences and obviously becomes less accurate. Group 2, however, can easily be divided into two sections. First, the species represented in figures 36 through 42 where there is relatively large variation in karyotype, and second, the rest of the species in Group 2 which have almost identical karyotypes. Within Group 1, the arrangement was first made on the basis of similar variation in the length of the Jut class of chromosomes; $J$ and $K$ relatively 3 horit and $L$ long (figs. $1-6), J$ short and $K$ and $L$ long (figs. 7 - 13), increasing length from $J$ to I. (figo. $14-30)$, decreasing length from $J$ to $L(f i g .3 I)$, and $J$ relatively Iong and $K$ and $L$ short (figs. $32-35$ ). Within these groups the order in the series was cletermined on the basis of variations in length in the GII elass of chromosomes and then, within these, in the variations in the ODFF class. Group 1 does not readily pall into distinct seotions as does croup 2. The karyotypes of I. regale, I. myriophyllun, I. Eargentiae, and I leucanthum var. chloraster (figs. 24 - 28) do form 
one clear Eroup, but anong the other species the variation is on about the same level, and while the scheme used for arrangement seems to give the most distinct division that is the only incication from evidence of chromosome morphology that the arrangement is natural.

With the exception of one species, I. Grayd (fig. 16), the position and distribution of secondary constrictions supports the separation of the genus into two groups. Although there are numerous exceptions, the secondary constrictions are found in the chromosomes with very short arms, nearer the centromere, and in the Iong arms, more often in Group 2 than in Group 1. Secondary constrictions are present in the A chromosone pair of all the species of Group 1 except I. Grayi, I. Duchartrei, I. Iongiflorum, L. fomosanum, I. giganteum, I. tsingtauense, I. candidum, and I. Brownif, and in the A chromosome of none of Group 2. Secondary constrictions are present in the $B$ chromosomes of approximately two thirds of Group 1 and in less than one fifth of the B chromosomes in Group 2 . One type of chromosome is peculiar to Group 2 and I. Grayi (fig. 16). These chromosomes have very small short arms and the occurrence of secondary constrictions in the long arms, very close to the centromeres, make eighty ifve percent or more of each chromosome a satellite. That these divisions represent natural groups could be determined by cytological methods only if the structural changes in the chronosones, few of which result in changes in chromosome morphology, are not so complex as to preclude analysis. The groupe must be closely enough related that hybrids can be obtained for analysis. From the cytological analysia of two hybrid forms as reported by Richardson (1935) and stewart and Bamford (1943) it can be inferred that the structural differences between 
apecies are numerous and complex. Thus any thorough analysis is probably impossible. Information from other sources comonly used to eraluate natural relationships consists of geographical distrilation, interfertility ox sterility, morphological structure, and physiological and growth characteristics. Information on these features gathered from the ilterature is considered in relation to the groups arrived at on the basis of chromosome morphology.

Ifiles are indigenous to the Northern hemisphere. Ires (1880) gives naps showing their distributions in three general areas. In North Amerlea, 8 species are found in the Eastern United States and Canada, two or three of them extending to the central states. Thirteen or fourteen species are found along the Pacific Coast. Io philadeIphicum has the wdest range of the eastem $117 i e s$ probably extending to the range of those on the Pacific Coast. In Europe and western Asia, eight or nine species seen to be native. The range of L. Uartagon extends across Siberia and probably to the areas occupied by the East Asiatic group. Lي. candidun has been coltivated for so many centuries that its origin is in doubt but it is probably from far east of its present concentration in South-Eastern Europe, The third area of diatribution 1s Eastern Asia where by far the largest number of species are found, at least fortyfive being reognived at the present time.

It is to be noted that the species of Group 2 , second section (figs. 43-48) are all natives of the Pecific Coast of North Anerica. The species of Group 2 first section (figs. 36 to 42) are all natives of kastern North Amerlca. OnIy three species of the European-West Asian group are reported here. As previously noted, the origin of Io candidiun is uncertain and the distribution of I. martagon reaches to the edge of the East Asiatic group: 
Two features of the karyotype of I. monadelphum (fig. 9 and plate 1) distinguish tt fron all other species. First the short arm of the $C$ chromosome pair is much longer than that of any chromosone in all the other spectes except for the and B pairs. Secondly, the F chromosone is the only one found with two moleolar secondary constrictions. How ever, lacking more complete representation of the species native to this reglon, the three are placed with the Bast Asiatic group which they resemble in all characteriotio much more than they do the North American group. Group 1 (flgs. 1 - 34) includes these three, twenty-five species native to Eastern Asis, and L. Gravi (flg. 16) found only in a small area in Southeastern United States. Thus, all the species of Group 1 except I. Grayi are Indigenous to the OLd World and all the spocies of Group 2 are from the New World. Variation in distribution of chromatin is correlated with geographical distribution.

The situation in I. Grayi is of considerable interest because it emphasizes how small the variations in chromatin distribution are. If the F chromosome suffered a structural rearrangement which rosulted in decreasing the length of its short arm enough to make it intermediate between the $H$ and I chromosomes a karyotype wovld result almost identical with that of the I. superbum type represented in figure 37. The idiogram would then have been placed in with those of Group 2, section 1. That the reverse of such a structural rearrangement has cocarred is probable because in every other feature. I. Gravi is comon with the species of Group 2. I. Gravi has no secondary constrictions in the and pairs of chromosomes which is the usual situation in Group 2. Chromosomes like its $\mathrm{K}$ pair are found elsewhere only in Group 2. : Its characteristics and behavior in all the phases of the following discussion are those of a 
member of Group 2 and it is hereafter considered one of that group.

Of approximately sixty nemed species hybrids listed by Slate (1939) and Woodcock and Coutts (1935), fifty-eight were crosses within Group 1 or Group 2 and only two were between the two groups. Emsweller (1937) Iists the interspecific hybrids reported to that date. There were 161 within one of the two groups and only seven were between groups. Two of the seven were the same ones reported by Slate and Woodcock and Coutts. Simonds (1939) gives a list of species hybrids of which one of 100 was between groups. Preston (1933) lists both successful and unsuccessful crosses. Of fiftyieight attempted intermgroup erosses, only one "succeeded." She recorded as successful an attempt which produced "apparentily good seed." It was not recorded whether the seeds were hybrids or apomictic as so many seeds produced in Iflium interspecific crosses are (stout 1938).

Slate (1939) lists groups of species he recomends as promising for the production of new hybrids because a survey of the literature and his experience hes shown relatively high fertility in interapecific crosses within these groups. The tirst group includes I. regale. L. sargentiae, I. myiophylium, and I. leucentiman. These species are all natives of Eastern Asia and have identical karyotypes falling in Group 1, adjacent in the arrangenent within the group. Slate's second group includes I. candidum, I. chalcedonicup, and L. testgceum. I. testaceum is a hylurid between the two species (kmsweller and stewert 1944) which are both representatives of the European-west Asian group. Only I. canaidum was available for the present study but while the chromosomes of these species were not presented by fusweller and stewart (1944) in a form directiy comparable to the laiogras in this report, it is evident that the Lo candidum 
of this study has the same karyotype as their Pype III which included an the bulbs they obtained from commercial sources. Their I. chalcedonioum evidentiy has the distribation of secondary constrictions and of chromatin characteristic of Group 1. Slate's third group includes I. martagon and I. Hansoni. OnIy L. martagon was examined. It is probable that the range of I. martagon extencis from Europe to East Asia where I. Hensoni is indigenous. The fourth group includes I. tig-

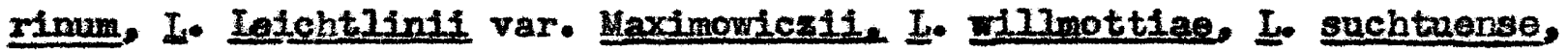
L. damricum, I. croceun, and I. batemannige. AII are natives of East Asia except Io crocean which is probably European although this species is another, cultivated for food since ancient times, whose origin is doubtful. I. IefchtIinii var. Maximouiczij and L. dauricum, the only two represented in this report, both fall lato the third section of Group 1 although they are rather widely separated within that section (figs. 18 and 20). I. tigrimm has previously been reported (stewart and Banford. 1943). Rearrangement of the ldiograms to the present order of decreasing length of the short arms from left to right shoms that they fit in the fourth section of Group 1. Slate's fourth group includes I. pardalinum, I. parmi, I. muboldtij, L. washingtoniamum. I. maritimun. I. columbianum, I. Roerli1. and I. parvum. AII these are natives of the Pacific Coast of North America and the idiograms of those reported here fall into the second section of Group 2. SIate's fifth group includes L. speclosum and L. aurature. These are both Asiatic and their Idiograms were placed in the second section of Group 1 , separated only by one species, I. monadelphin (fig. 9). Slate's sixth group adds I. Eenryi to his first group. This species is also a nativo 
of East hsia and its idiogram foll in the same section of Group 1 as the I. resale eroup. These data show interspecific sterilfty to be correlated with the variation in distribution of chromatin.

Stout (1928) classifies the bulbs and bulb habits of Lifinm. The European and Asiatic species (Group 1), with few exceptions, have concentric bulbs. The bulbs of the North American species (Group 1) are all rhizonatous. The bulbs of the Pacific Coast species (section 2) differ from those of the Fastern species (section 2) in that the rhizone between the wother and daughter bulbs is covered with scales. Thas variation in bulb structure is correlated with variation in the distribation of chromatin.

Lijirm has not been the subject of scientific researches designed to elucidate the physiological systems of the species. Slate (1959) makes the following general atatements based on his experience growing many species and from a survey of the literature. On page 48 , he states: nThe Asiatic lifies are moh in color and diversity of form. They hybridize well among themselves, but poorly with the other lilies.

many of this group are fairly easy in gardens and usually flower well the fjrst year. As a group, they grow rapidiy from seed, although a few do not come up until the second year. They are mostly stem rooters and a few have wandering stem bases." On page 49 , relative to the specles native to Europe and Western Asia, he states "Few are sterh-rooting and as a group they tend to anlk for a year or two after removal. They grom rather slowly from seed -... On page 49, relative to the species native to Eastem America and the Central States: "These are slow from seeds, which come up the second year, mostly base-rooting or with weak sten roots, and have stoloniferous bulbs and pendulous florers except I. philadelphicum and I. Catesbael. Except for I. philadelphicum. 
they do not hybidize with other lilies." on page 50, concerning the species native to Fastem America: "The Pacific Coast Illies, except for L. pardaliman and I. Eumboldtil, are usually more or less difficult garden subjects, slow from seed, and have rhizomatous or sub-rhizomatous bulbs. The bulbs of some do not handle well and are not easily established. Some have jointed scales. They are a clamish lot and hybridize only among themselves g

It is probable that physiological and growth reactions to cultural conditions are correlated with geographical distribution and thus with distribution of chromatin.

The gems lifium is at present divided into two subgenera. Cardocrinum includes the species with netted veined, heart-shaped leaves Wth long petioles. The flowers are long, narrow, funnel-shaped, and horizontal in position. The only three species included are Asiatic; namely. Io cathayammi, I. cordatum, and L. giganteum. The subgenus, Qulirion, contains all the other lilies and is divided into four sections on the basis of shape and position of the flower. Ieucolirion has funnel-sheped flowers usually horizontal in position and representatives of this section are found in Forth America, Europe, and Eastern Asi2. Archelirion has horizontal bowl-shaped flowers and the one repsentative of this section, L. auratum, is Asiatic. Isolirion has erect, bowl-shaped flowers and representatives are found in all threo geographical areas of distribution. Martagon has nodiing flowers with strongly recurved perianth segments. Representatives of this section are found in all the areas of distribution.

Endlicher (1856) proposed the present classification and it has been accepted with small modifications by Baker (1874), Wilson (1925), and 
others. However, evidence of new intermediate species and breeding behavior has indicated need for revision of the genus into more natural groups. Hes (1880) was probably the ifrst to suggest this. entIy, Woodcock and Coutts (1935) have stated on page 71: "It is obvious that too much attention has been paid to a single feature - the curving and poise of the periantb-segments (i.o., the sepals and petals). Probably this rather artificial and by no means satisfactory system will be considerably revised in the future, and we may expect to see the elaboration of a new and more natural classification based on a greater range of characters, Including the form of the bulb and its mode of development and increase; the American species now referred to Martagon and Leucolirion will be recognized as having no close affinity with the old vorld representatives of these groups."

Plate 1 consists of photoidiograms of one species from each of the sections in malirion and one spocies from Cardocrimum. It is ovident that all five species have very similar idiograms. The distribution of chromatin in 211 is characteristic of croup 1. Shape and position of flower, the basis for the present classification, is negatively correlated with chromosome morphology, interspecific sterilities, geographical aistribution, bulb structure and growth, and physiological and growth characteristics expressed in reaction to cultural conditions. The lattar are positively correlated and are suggested as a basis for revision of the genus.

There is no direct evidence to be obtaine i rom a study of somatic chromosone morphology as to the method of origin of the variation between karyotypes. Indirect evidenee was secured from consideration of the lower levels of the variation evident within a species type and between 
a species and its varieties. There was variation of two kinds. First. there was the presence of extra chromosomes in Is auratura (fig. 10), Io tsingtauense $(f i g, 15)$, L. Henry $(f i g \cdot 20)$, L. Sargentiae Horsford (fig. 27). and I. pumilum Golden Glean (fig. 35). These centric fragments and chronosomes appeer very much like those reported by stewart (1943). Ixamination of meiosis at that time revealed evidence of non-homology with any and all of the normal complement and no indication of their origin. The secord type of variation is in the number, position, and activity of secondary constrictions with no change in chromatin distribution. This was found in I. concolor (figs. 1 and 2), L. speclosum varieties (figs. 7 and 8), I. auratum (figs. 10, 11 and 12), I. dauricura and Is. dauricum var. 留Isont (fig. 29), and L. superbum (figs. 36 and 37 ).

Two cases seem particularly significant. Rxamination of the karyotypes of two groups of individuals in I. guperbum, represented by tho idiograns in figures 36 and 37 and of the idiograns of the rest joast species in figures $43-48$, reveals the fact that, if the change were from the idiogram presented in figure 37 to the idiogran in figure 36 , it would be toward the karyotypes found in the west coast species. rhis change could have been accomplished by change in the nucleolar organization of the karyotype only, which has been shown to be the nost variable feature of the karyotype in Iillum.

Bxamination of the netaphase and anaphase figures in L. dauricum and I. dauricum var. 1 isoni $(f i g$. 29) showed identical chromatin distribution as well as the same number and distribution of secondary constrictions. The two karyotypes were found to differ only in the mucleolar activity of the secondary constrictions in the long arms of the $\mathrm{C}$ and pairs. In the type, one chromosone of each pair was almays associated 
with a maloolus at prophase or always showed the secondary constriction at metaphase. The other members of the pairs rarely showed the constriction at metaphase and were not seen associated with nucleoli in approximately thinty prophases examined. In the variety, the constrictions showed very rarely at metaphase and were not observed associated with the moleoli at prophase. It is probable that examination of large numbers of prophases would have revealed the rare associations indicated by the equally rare appearance of the constrictions at metaw phase.

A possible case of difference within a species in a measurable anount of chromatin is indicated by the examination of the $F$ pair of chromosomes of I. pardalimu (fig. 45) and of the $F$ and F' pair of I. pardalimup var. giganteum (fig. 43). The origin of L. pardalinum var. giganteum is doubtful and many consider it a hybrid of the L. pardalimu type with some other Pacific coast species. None of the Pacific Coast species reported here has a chromosome or chromosome pair corresponding to the F' chromosome of L. pardalimun var. giganteum, and no critical evidence has appeared.

Ensweller and Stewart (1944) found three types of variation within species. In L. candidum the plants were either heterozygous or honozygous for the secondary constriction in their $C$ chromosome pair. In one clone, the distribution of chromatin was markedly altered by the translocation of a large part of the lone arm of a K chromosome to an A chronosone. Their type III, similar to the three plants here reported, and type IV differed from the rest in that one of the I pair of chromosomes had measurably less chromatin in its short arm giving one I chremosome and three $J$ chrozosomes in contrast to two of each for types I and II. Five 
E. chalcedonicum plants showed high îrequencies of several different sets of hetermorphic pairs but a comparison of length showed the diffarence to be only in the presence or absence of secondary constrictions. Haga (1943) reports a plant of I. hansonit heterozygous for a reciprocal translocation. His figure 10, pp. 22 indicates the plant is also heterozygous for two inversions, one in a chrorosone with a subuedian centromere and one in a ehromosome with a subterminal centromere. The chromosones of IfIlum species hybrids are known to naintain the arn Iength ratios and constrictions of the chromosomes of the parent species (Laney 1943; Emsweller and Stewart 1944). This knowledge of the karyotypes of the parent species rould allow selection of sexual hybrids from the precominantly apomictic progenies usually resulting from interspecific crosses in Iilium. This should be especially valuable in plant groups which require several years to flowering and selection on the usual morpholocical basis.

The limitations of sonatic chromosome norphology as a tool in tracing phylogenetic relationships has been emphasized by many geneticists who point out that "the similarity or dissimilarity of the chromosomes as seen at the metaphase plate stage is not at all necessarily proportional to the similarity of their gene arrangenents" (Dobshansky, pp. 133, 1941). Several types of structural changes, such as inversions and reciprocal translocations where exchange is equal, may occur within chromosomes and not affect their external morphologyl These chenges can be detected only at meiosis and a cytological study of hybrids is indicated ss necessary to determine species relationships and differentiation. Very fow gene matations have beeri shown to affect chromosome morphology. Ilowever, the 
accumulation of mtations has been accepted as a nore important factor in speciation than structural rearrangement of chromosomes. Thus, genetic studies are the most critical means of evaluating relationships.

whe ciata on chromosome morphology of Iilium has shown that it is not critical evidence at a species level. In three instances, groups of plants recogrized as containing several distinct speciss have proved to possess identical karyotypes. On the other hand, closely related species and even different individuals of a single species have shown veriation in karyotype. It is at this level that cytology and genetics of hybrids will give the best evidence of phylogeny. The similar karyotypes will probably reveal hidden inversions, translocations, and gene differeuces. The rariable karyotypes of single species or closely related species vill probably be shown to differ by relatively simple chranosome rearrangenenta and small changes in genowes. It is at the higher lovels of differentiation that chromosone morphology cast replace those tools. Wien the sterility barriexs between groups become complete chromosome norphology and numbers are the most critical evidence that can be obtained. At these higher levels chromosome norphology has indicated natural relationships in Iilium.

$$
\text { SUPBAK }
$$

The karyotypes of forty-eight species and varieties of Iilium have been detemined. The idiograms presented represent the haploid complement of a somatic metaphase arranged with centromeres along a horizontal line and with the chromosomes in order of decreasing length of short arms. "The activity of all constrictions was detemined. The meleolar activity of secondary constrictions classed as nucleolar was found to be variable and in one case this variation was the only difference between the karyotypes 
of a species and is variety. Eallure of nomally nucleolar secondary constrictions to form nucleoli was found to be a cause, along with fuston, of the frequent reduction. from the riaximm in the rumber of moleoli in resting cetls. The maxirum mam of moleoli in filiud species was found to vary from four to fourteen. The naximn mamber of moleoli in resting cells was determined for all the species of Ifliu reported. It was in all cases equal to the maximun muber of chronosones observed associated with molooli at secondary constrictions in prophasos. In all but one species of over forty exanined, there were additional secondary constrictions which were non-rucleolar. Variation in position of secondary constrictions was found to be comrelatod with differencas in geographical distribusion.

The variation of distribution of chromatin witivin species was the basis for arranging then into related groups. These groups are considered natural because the same groups are reached on the basis of geographical distribution, interspecific fertility and sterility, bulb structure and physiologioal and growth responsas to caltural conditions. The present classification provides entirely different groupings and revision is suggested. Winile chromosome norpholosy has indicated natural groups witum the senus Iling, its usefulness in differentiation of species is linited by the independent occurrence of karyotype variation and gene mutation. The accumalation of gene differences is recognized as the rast important factor in speciation. 


\section{LITERATHE: OITED}

1. Babcock, B. 1944. New light on evolution from research on the genus Crepis. Axs. Nat. 78:385-409.

2. and J. A. Jenkins. 1943. Chromosomes and phylogeny in crepis. III. The relationships of one hundred and thirteen species. Univ. Calif. Subl. in sot. 18:241-291.

3. L. J. Stebbins, Jr., and J. A. Jenkins. 1342. Genetic evolutionary processes in Crepis. Am. Nat. 76.387-363.

4. Baker, J. G. 1874. Reviston of the genera and species of Tulipeae. Jour. of the Iinnean Soc. (Botany) 14:211-310.

5. Beal, J. W. 1942. Chromosome fragments in Lilium wilmottiae and hybrids between it and L. davidif. Bot. Gaz. 103:617-619.

6. Cooper, D. C. 1935. Macrosporogensis and development of the embryo sac of Lilium Denryi. Bot. Gaz 97:346-355.

7. 1936. Development of gametes of Ijlium. Bot. Gaz. $98.169-177$.

8. Dermen, $z_{\text {. }}$ 1933. Origin and behavior of the nucleolus in plants. Jour. Arn. Arb. 14:282-323.

9. Dobzhansky, i. 1941. Genetics and the origin of species. columbia Univ. Press, New Tork.

10. Elwes, J. H. 1880. A monograph of the gems Lilium. Faylor and irancis, London.

11. Bmsweller, S. L., P. Brierley, D. V. Lunsden, and F. L. Lulford. 1937. Inprovement of flowers by breeding. U.S.D.A. Yearbook Separate No. 1591. pp. 890-998.

12. and kaydelle 13. Stewart. 1944. The origin of Iilium testaceam. Jour. of Heridity. 35:301-308.

13. Lindlichers, S. 1836. Genera plantarum. Vindobonae, Vienna.

14. Femandes, A. 1936. Les satellites chez les Narcissis. II. Tes sabelitites pendant Ia bitose. Bot. Soc. Broteriana 17:8\%-146.

15. Gates, N. H. 1942. Nucleoli and related nucleolar structures. Bot. Rev. 8:337-409.

16. Coodspoed, T. E. 1945. Cytotaxonony of Nicotiana. Bot. Rev. II: 650502.

17. Faga, 1. 1943. A reciprocal translocation in Lilium liansonj Lejcht. Cytologla $13: 19-25$. 


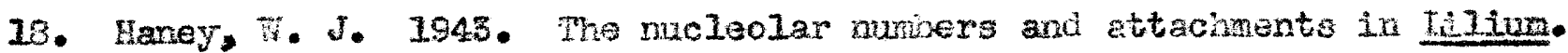
Ph. D. Thesis, Unive of Maryland.

19. Feit, r. 1931. Die ursache der gesetrmassigen zahl, Lage, form wnd grosse aflanzlicher mucleolen. Flanta 12:774-344.

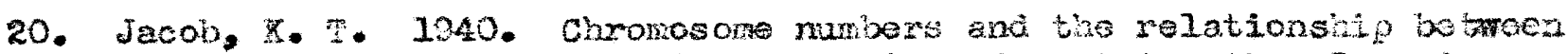
satellites and rucleoli in Gassia and certain other Leguininosae. Sin. Bot. n.s. 4:201-226.

21. Nather, K. 1934. The chromosones of Lilime. II. H. T. Tily Yaarbook $3: 38-40$.

22. 1938. Meiosis in Hilium. Cytologia 6:354-380.

23. Matsura, 17. 1938. Chromosome studies in Trillium kamtschaticum

Pall. Hi. Oa the mucleolus chrouosone relationship. Gytologla $9.55-77$.

24. Preston, I. 1935. Hybrldization of lilies. F.H.S. Iily Yearbook $38173-193$.

25. Fesende, 19. 1937. Jber die ubiquitat der SAT-chromosoner bel den 3litenpflansen. Planta 26:757-607.

26. Richardson, 唯argret. 1936. Horidity in Tiline rartagon album I. Hansonil. Jour. Ger. 32:41I-45I.

27. Seneone, t. R., and L. Lacour. 1934. The chronosones of Hilum. III. R.I.S. LiIV Yearbook 4:40-45.

28. Sato, D. 1932. Chromosome studies in Iilium. Bct. Mag. (Toloyo) $46: 60-8$.

20. 1035. Karyotype alteration and phylogeny. W. Karyotopes in Anaryllidaceae with speclal reference to the sAl-chromoscue. oytologia 9:203-242.

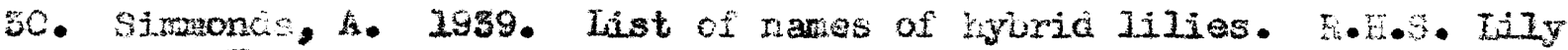
Yearbook 9:40-61.

31. SIate, A. T. 1939. Iilles for Amerticen Gariens. Scribners, Nem York.

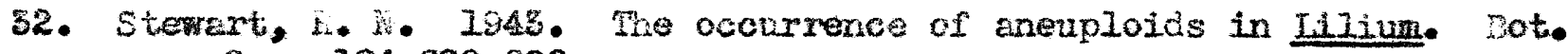
Gaz. $104: 620-626$.

33. ㄴ. snd R. Banford. 1942. The chromosones and nucleoli of Leciela vireiniena fmer. Jour. Bot. 20.301-308.

84: - - 1545. The nature of polyplotiy in Iilium tígrinum. Amer. Jour. Bot. 80:1-7. 
35. Stout, A. B. 1928. The bulbs and bulb habits of 1ilies. Jour. i. I. Bot. Garden 29:25:12.

36.

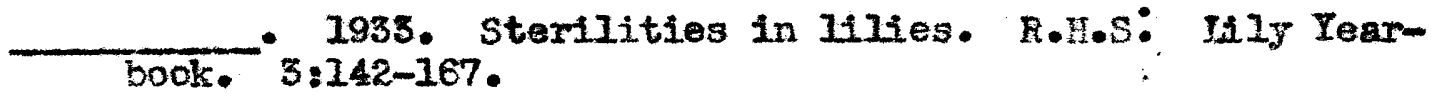

37. Takenaka, $X_{4}$, and T. Naganatsu. 1930. On the chromosones of Yi7ixia tigrinum Rer-Gawl. Bot. 1 ag. (Tokyo) 44:386-391.

38. Wilson, E. H. 1925. The lilies of Bastern Asia. Stratford, Boston.

39. woodcock, H. D., and J. Coutts. 2935. Iilies, Country tife, Londion.

40. Woods, 供. 再. 1987. The mucleolus in Tuliga. Amer. Jour. Bot. 24: $520-536$.

41. Van camp. 4. 11 . 2924. Ie role du moleole dans la caryocinese somatique. Ia. Cellule 34:1-60. 
I. concolor Salisbury

L. Browniti F. E. Brown

L. candidum Linnaeus

L. callosum Siebold and Zuccarini

I. Davidis Duchartre

L. speciosum var. album listers

L. speciosum var rubrum Masters

I. speciosum var. maenificum haters

L. speciosum var. punctatum Courtois

I. monedelphum Bieberstein

L. auratum Iindley

L. giganteum wallich

L. tsingtauense Gilg

E. Gravi S. Watson

L. Japonicum Twunberg

I. Leichtinini var. Laximoniczii Baker

L. Lenrai. Baker

I. martazon Linnaeus

L. Longifleam Thunberg, Horticultural forms Creole, Estate and Slocum's Ace.

L. formesanum Wallace

I. regale tilson

L. Eyacioghrzlum Franchet

L. Sargentiae 麗ilson

L. Sargentiae Filson, Hort. form Horsford

L. Leucantimin var. chloraster w1lson 
I. dauricum Ker-Gawler

L. dauricum subsp. Thunbergiange $f$. Alice 䨨ilson Wilson

L. Duchartrei Franchet

L. 进然拄 Stapf

I. amabile Palibin

L. Dumilum De Candole

L. punjium De Candole Hort. var. Golden Gleam

L. superbum Iinnseus

I. philadelphicum Iinnaeus

I. Catesbaei Walter

L. carolinianum Hichaux

I. michicanense Farwe II

L. canadense IInnaous

L. canadense var. Llavum Pursh

L. canadense var. rubrum Britton

L. pardalimum var. giganteum Kellog

L. Roezlil Regel

I. pardalinm Kellog

L. Barrya S. Watson

I. occidentale Purdy

L. columbiamum Hanson 
PLATE I

Photonicrographs of representatives of subgenera and sections of goms Ifiliua.

Sabgeras Emirton, Section Isolirion. - I. concolor

Subgems Bulirion, Section Ieucolirion. - E. Bromit

Subgerms Gardiocrinum. ...... - In giganteun

Subgenns Lirion, Section Martagon. - . I. monadelphum

Subgemas Eulirion, Section Archelirion - Ie auratan

AII $\times 2700$ 


$$
\begin{aligned}
& \text { !̣́ililili!) } \\
& \text { Iiii!ili!! } \\
& \text { ) (1111110) } \\
& \text { flifi!il(1)! } \\
& \text { I)! } 51111110
\end{aligned}
$$




\section{PIATE 2}

Photomicrograph of somatic taphase plate from root tip of I. cancelor (type 2) pre-treated with colchicine. Photographs of the chromosomes from this cell were used in the photoidlogram in Plate 1. X2300. 

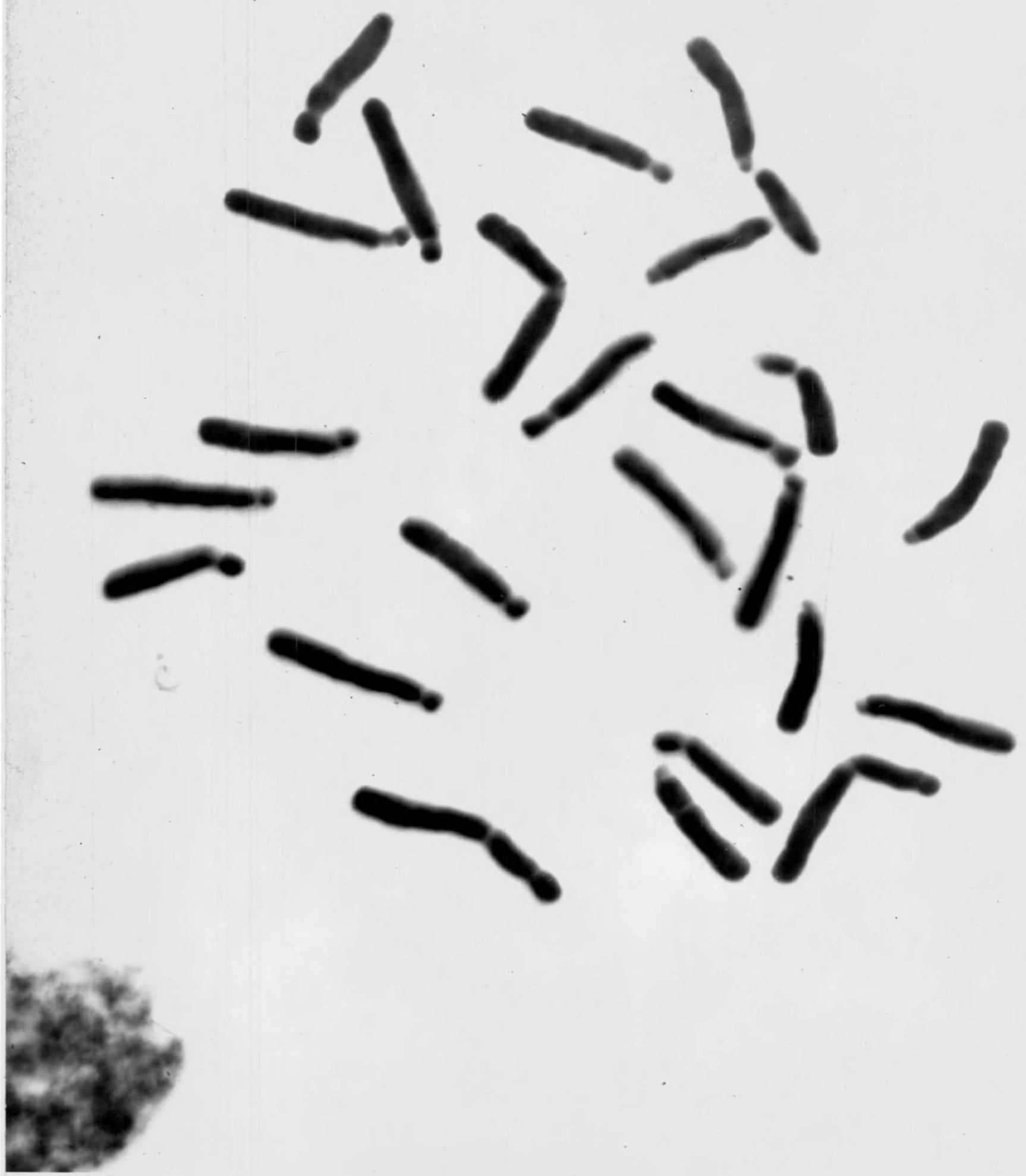

PLATE 2 


\section{PLATE $\mathbf{3}$}

Photomierograph of somatic metaphase plate from root tip of L. Bromif pre-treated with colchicine. Photographs of the chromosomes from this cell were used in the photoidiogram in Plate 1. X2000. 

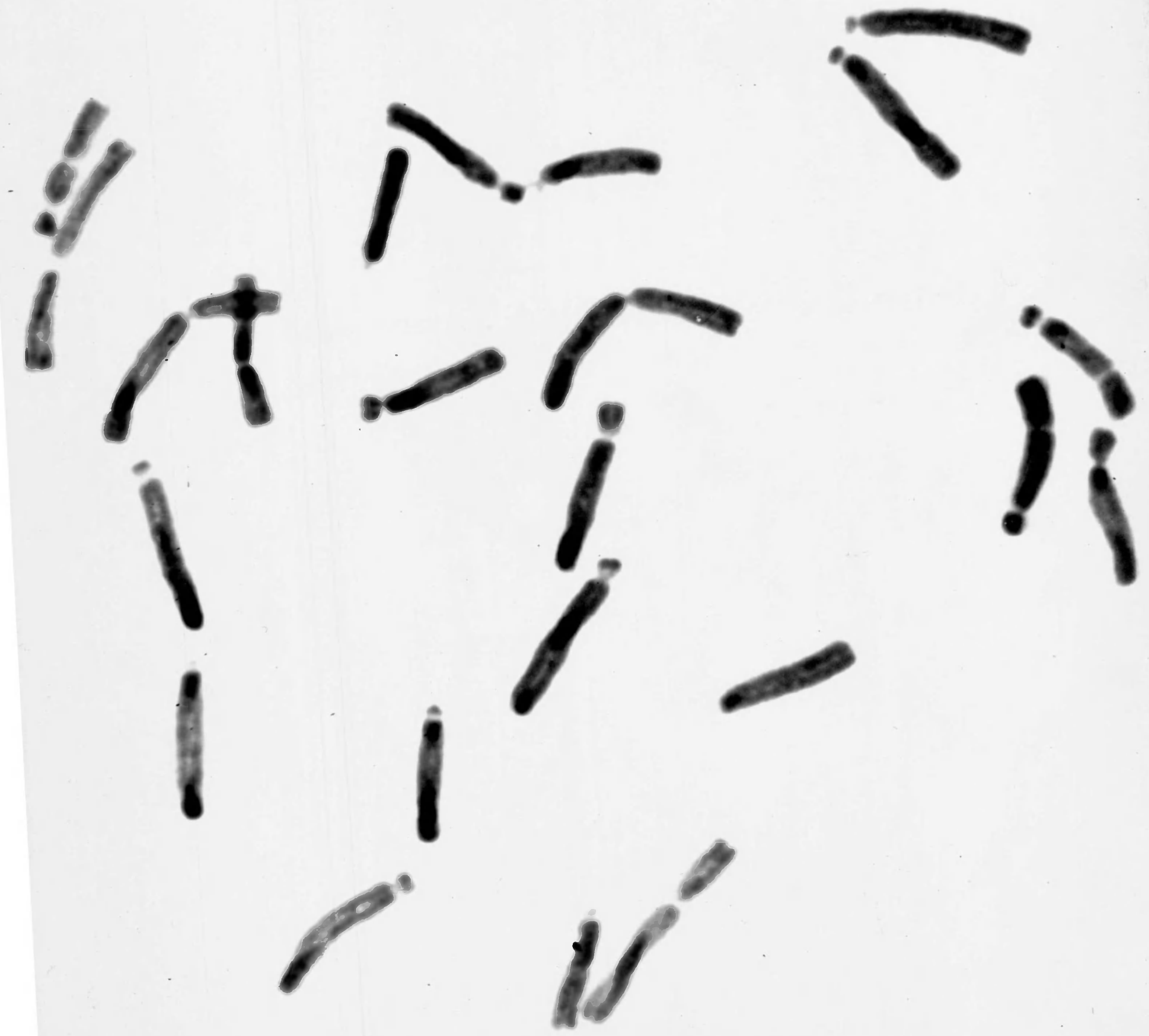

1

PLATE 3 


\section{PLATE 4}

cunort Inold draning of prophese cell from root tip of

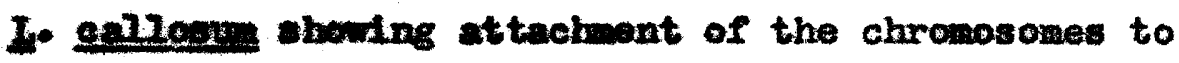
maleall at beoondary conotrictions. Both chronosomes of palrs $4, G$, and $I$ and ono chromosone of palr $F$ are whown attachod to maleoll. $\mathrm{x2500.}$ 


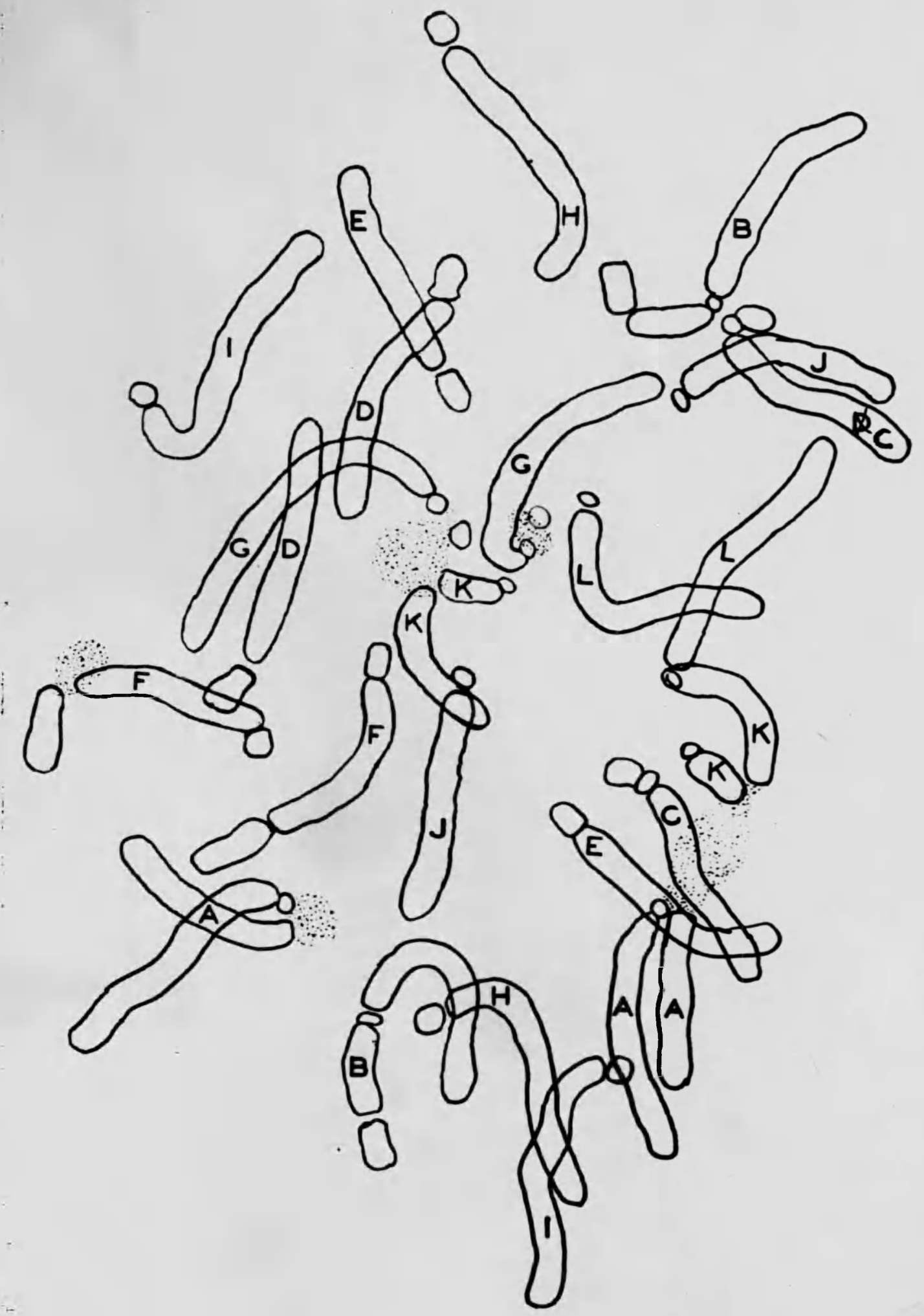

Plate 4 


\section{Pan 5}

Photenderograph of prophase cell of to callosum arawn in Plate 4. X2s00. 


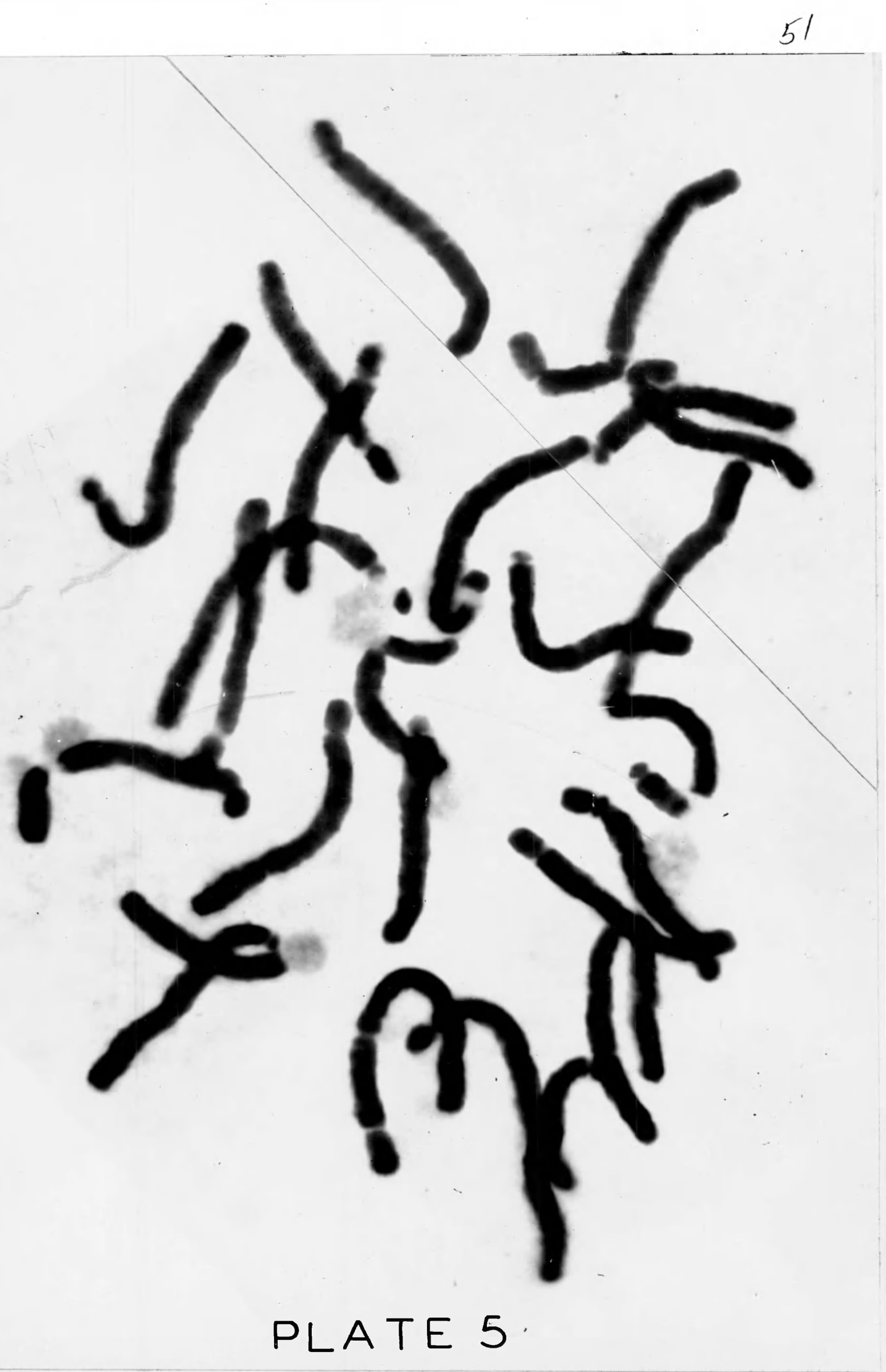




\section{6}

Photchleregriph of prophase cell frem root tip of I.

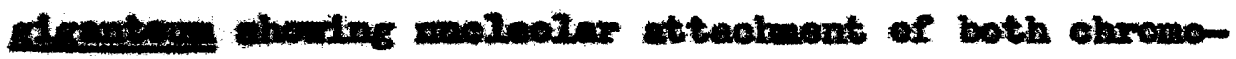
cenos of the C and D patre and one chremosene of the $\mathrm{D}$ patr. weas 


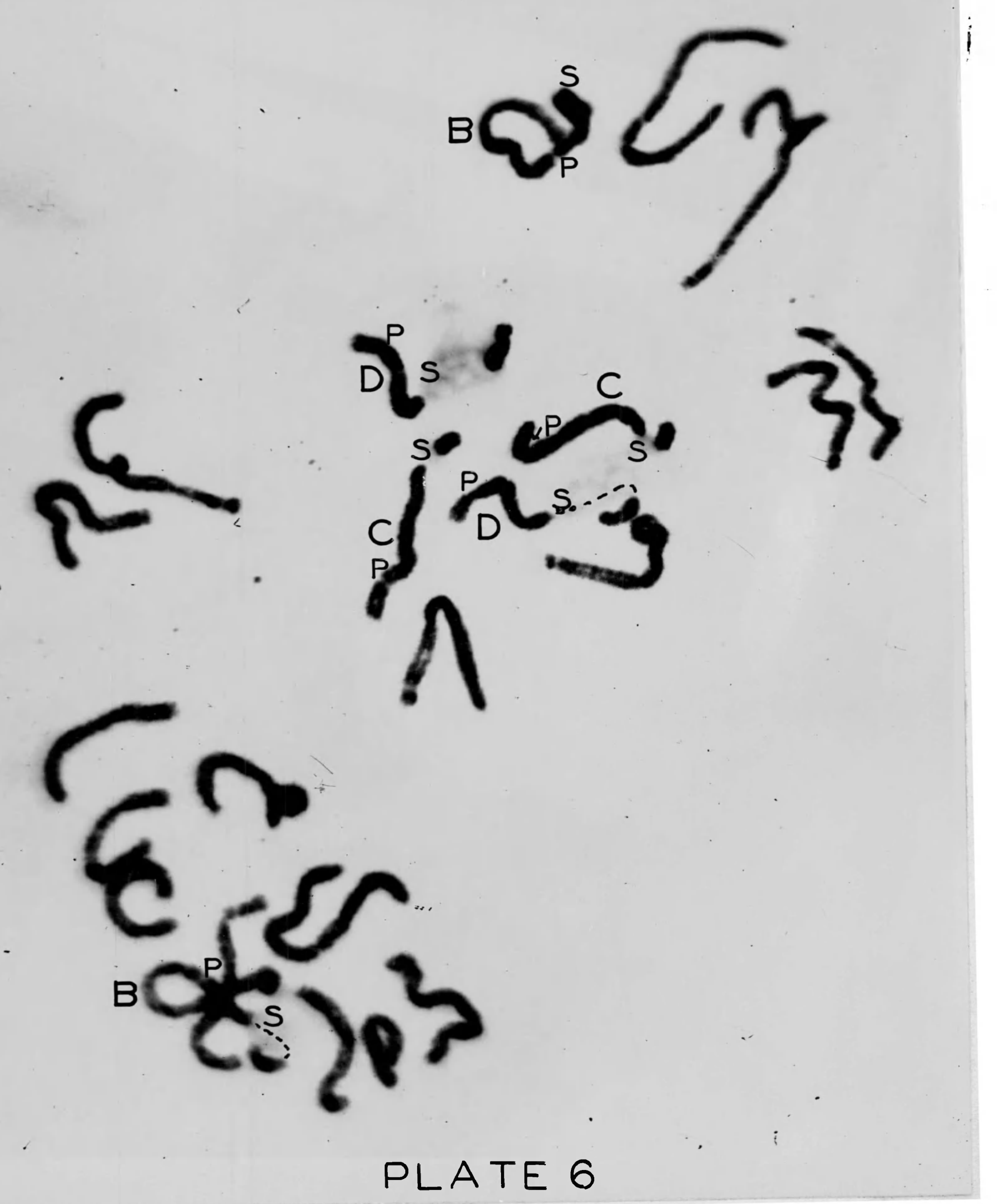




\section{PLATE 7}

Photomiarographs and canera lucida drawings of the nucleolar chromosomes of L. Sargentiae f. Horsford. The constrictions of the flve chromosomes pictured at metaphase are classified ntilizing information from the other mitotic phases shown. $P$ - primary constriction or centromere. $S_{H}=$ secondary constriction, mucleolus forming. $s$ - secondary constriction, nonnucleolus forming. Prophase shows nucleoli at the nucleolar secondary constrictions except in the $D$ pair, neither of which were attached to nucleoli in this particular cell.

The non-mucleolar constrictions are never found attached to nucleoli. The late metaphase chromosomes show the beginning of separation at the primary constrictions while secondary constrictions still Ife together. Anaphase chromosomes show the positions of the primary constrictions oriented toward the poles and secondary constrictions usually attemuated if they cut off a large mass of the chromosome. X2600. 


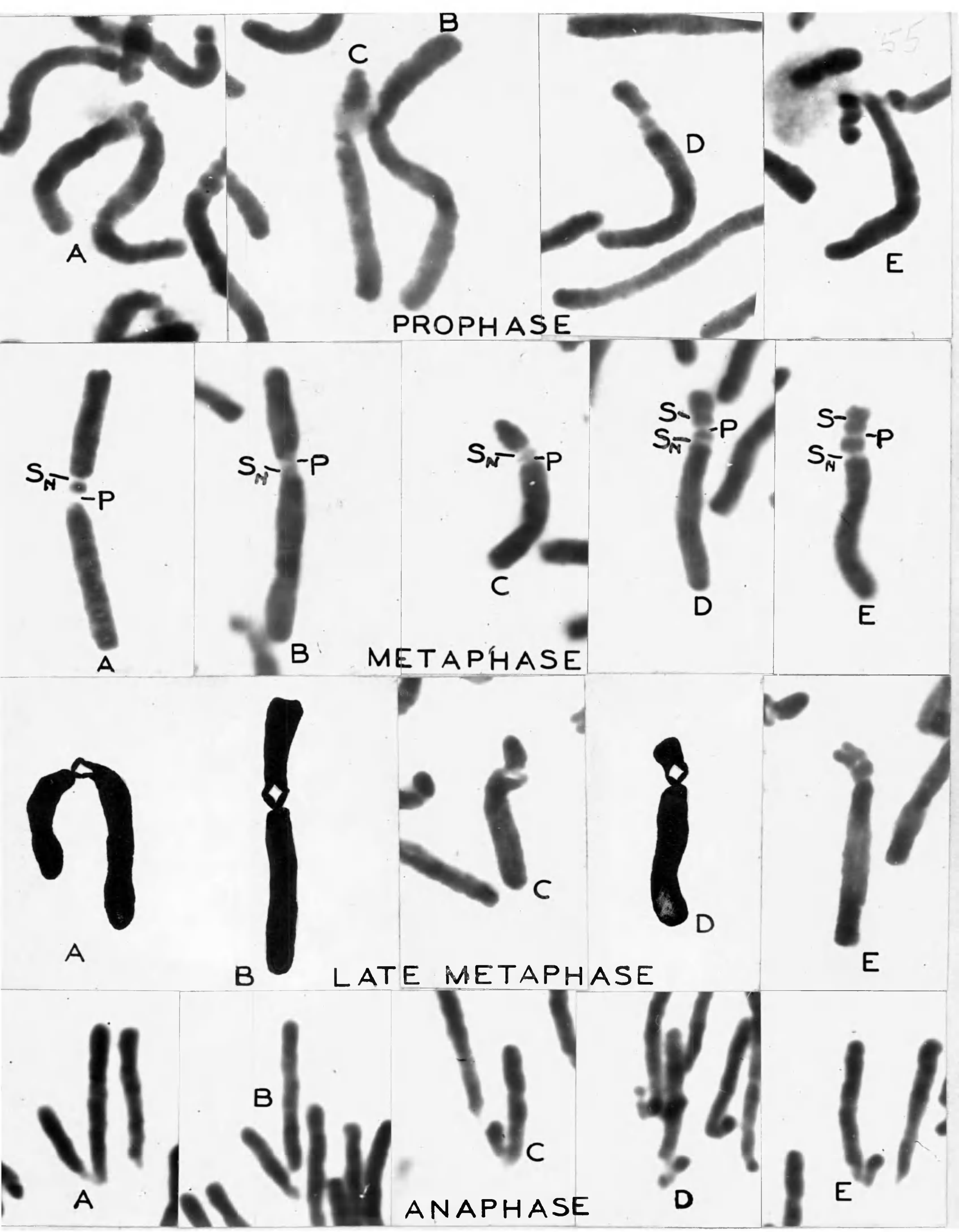


2xins 8, $9,10,12,12,18$

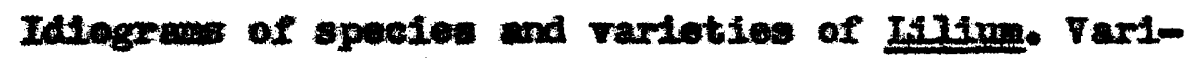
attons within opectes aro shown eeparately. $\mathbf{2 0 0 0 .}$ 


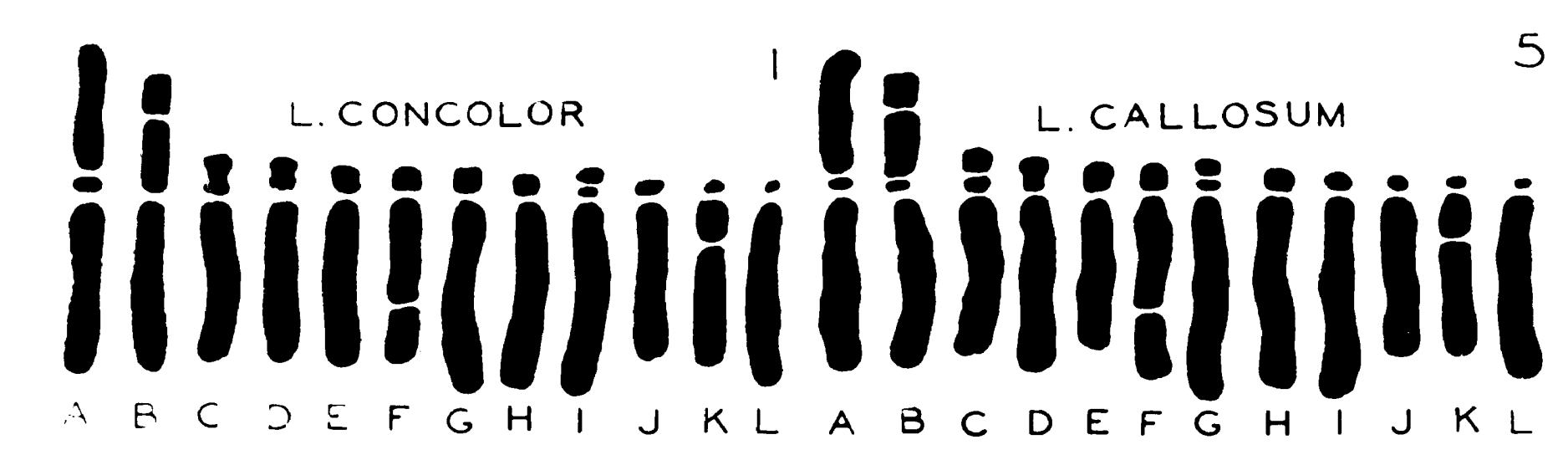

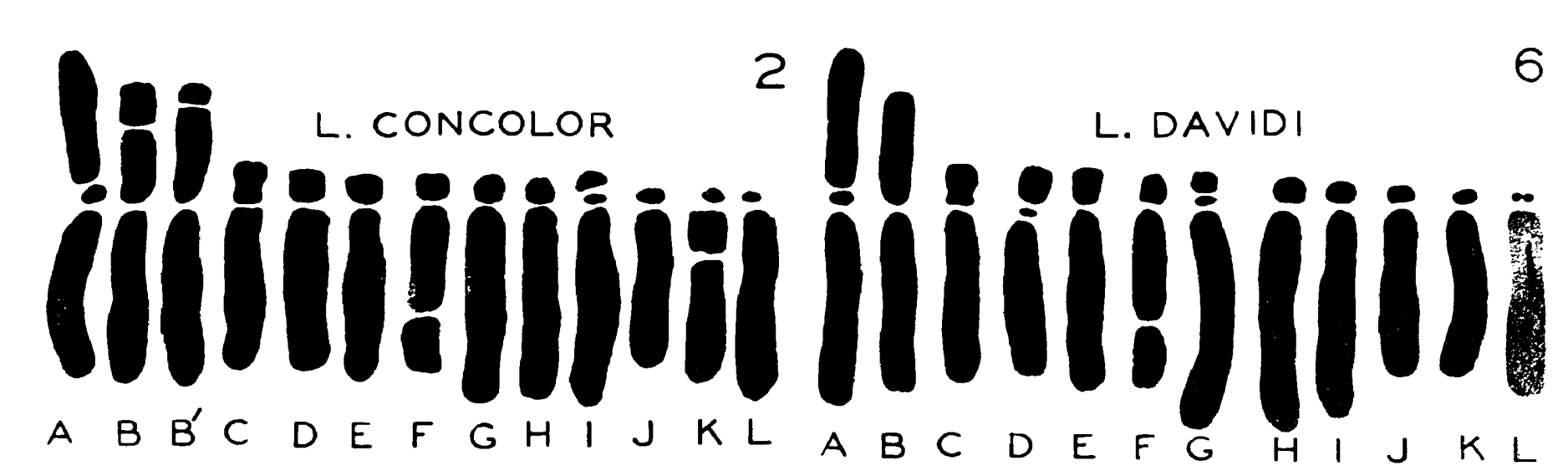

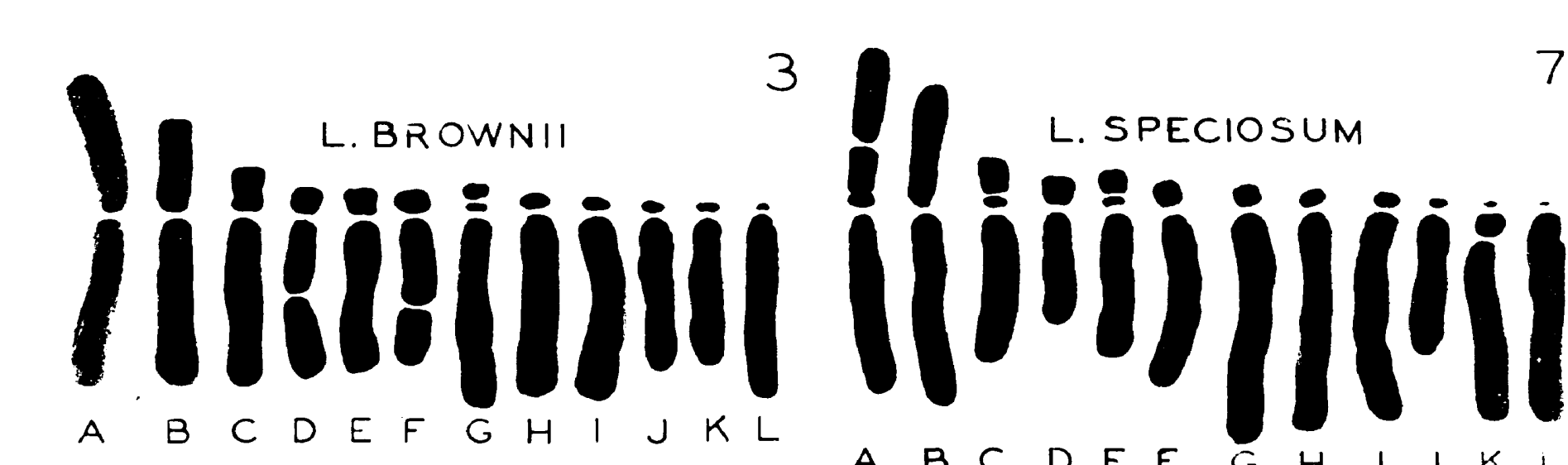

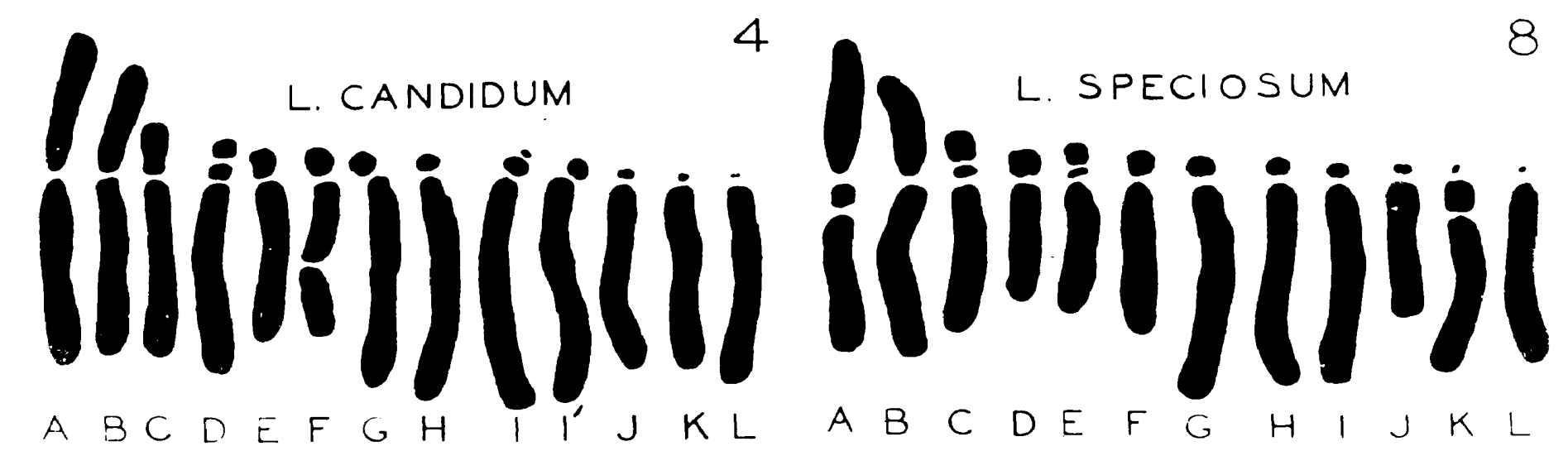


Hibiji(jicillikiijijii)

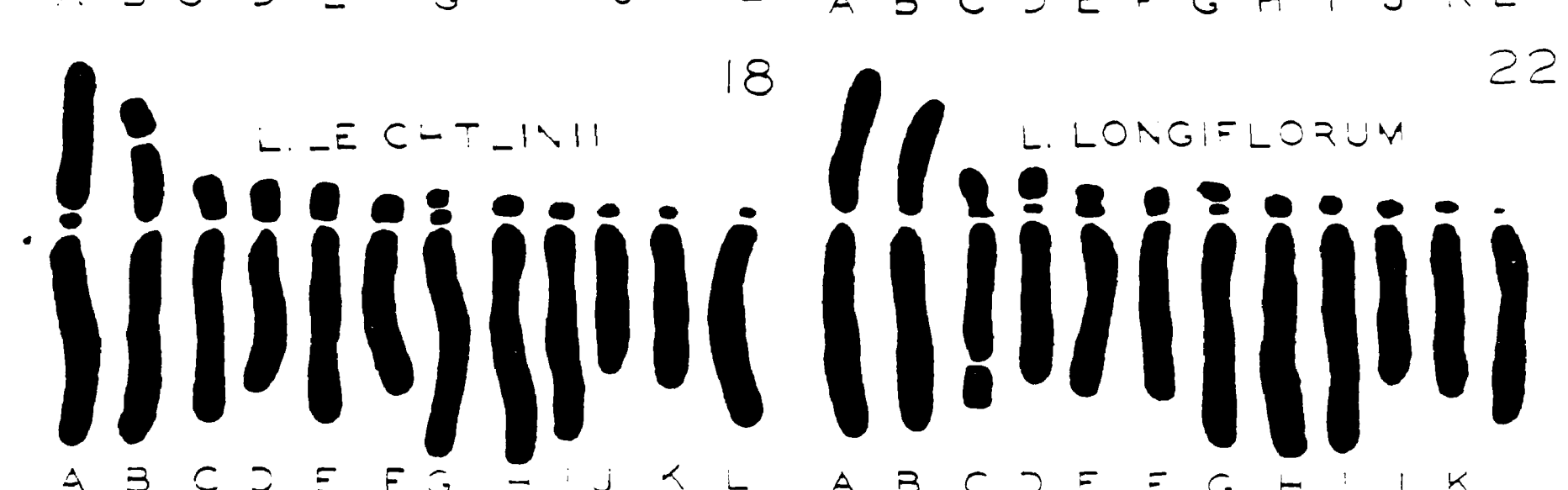

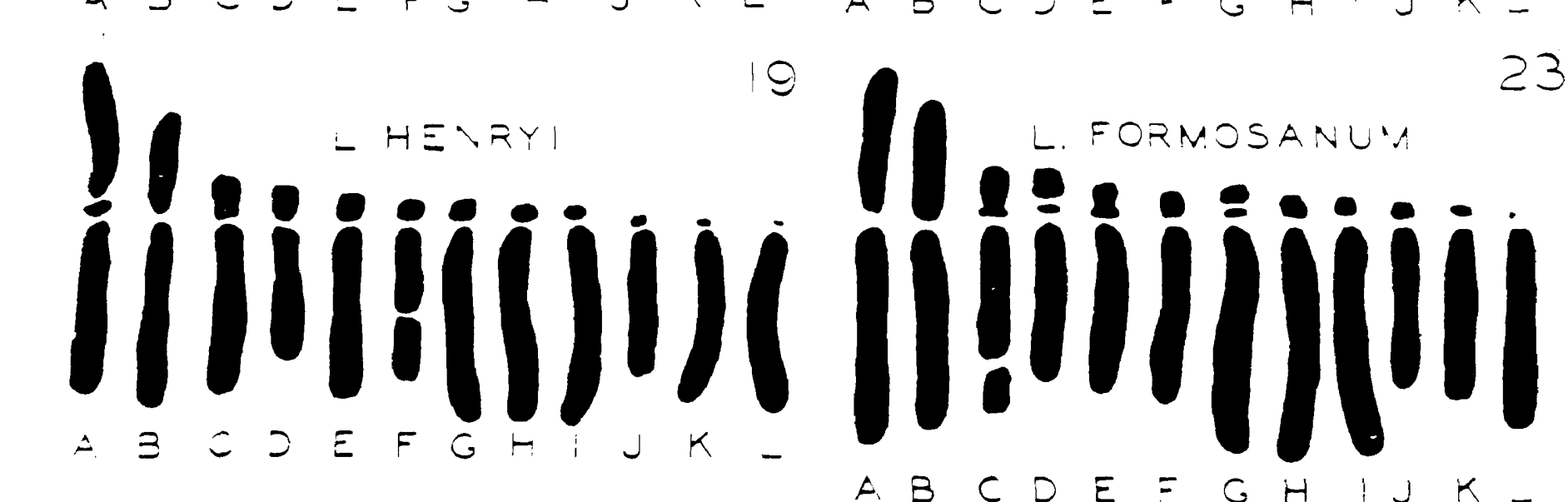

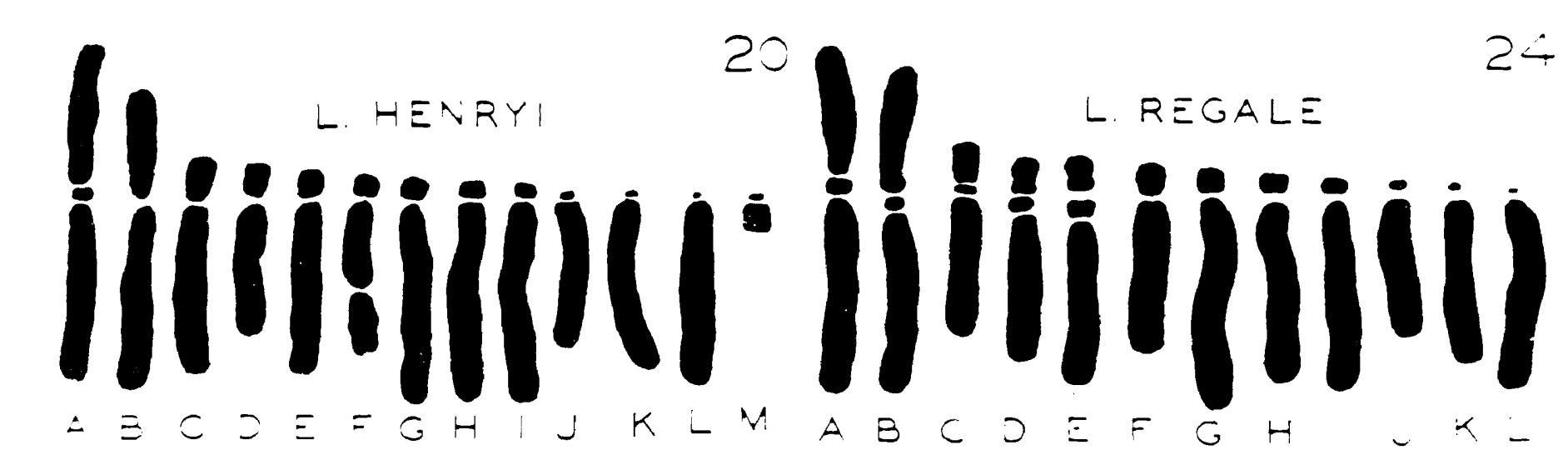


(ini(i)ijij(i)i(j)i(ji(ji)

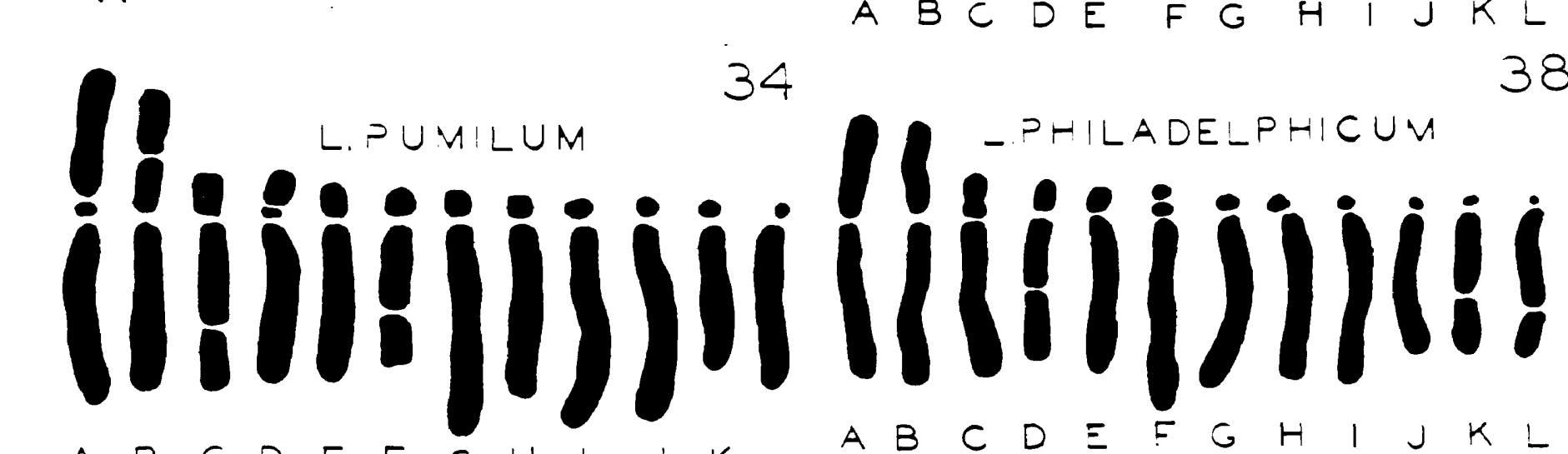

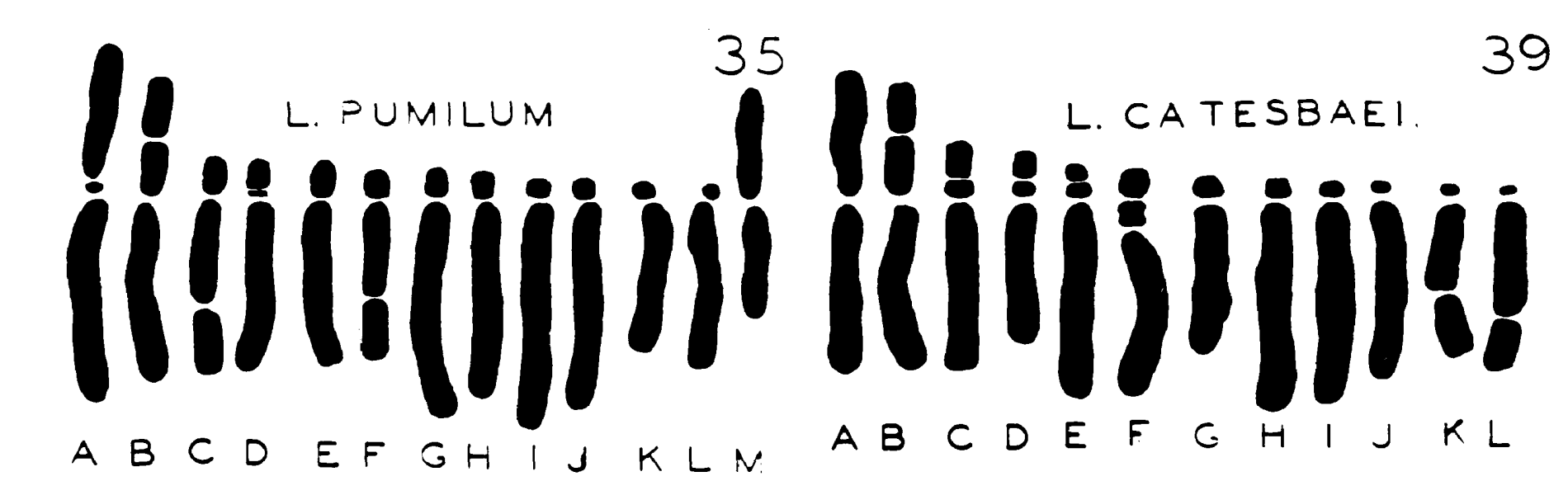

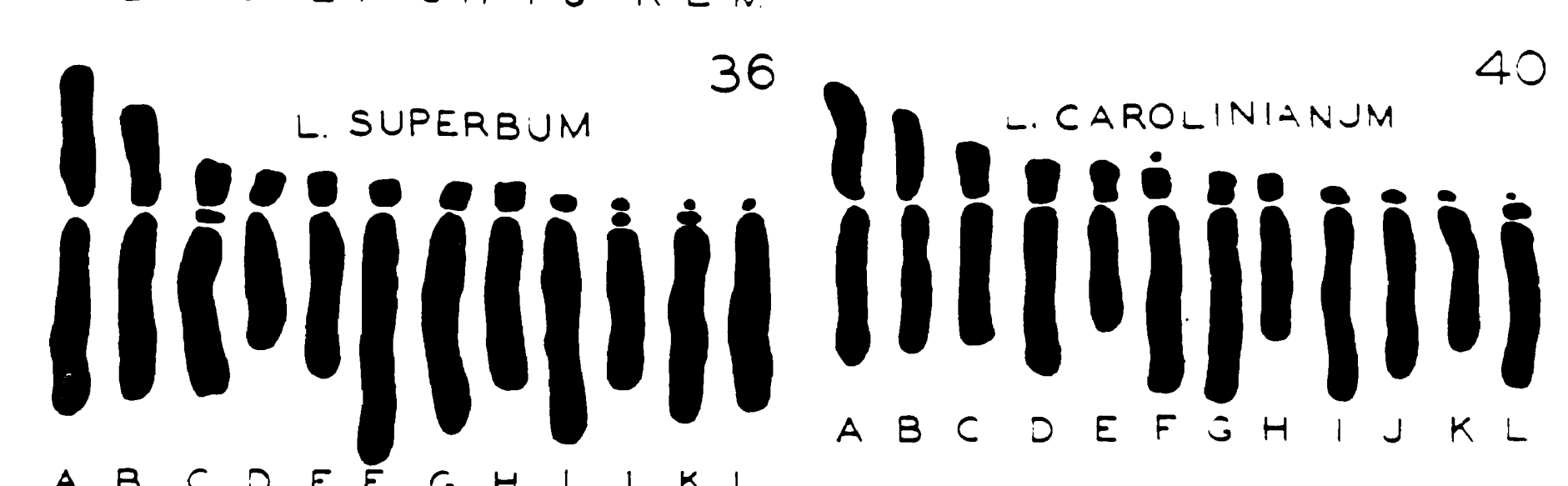




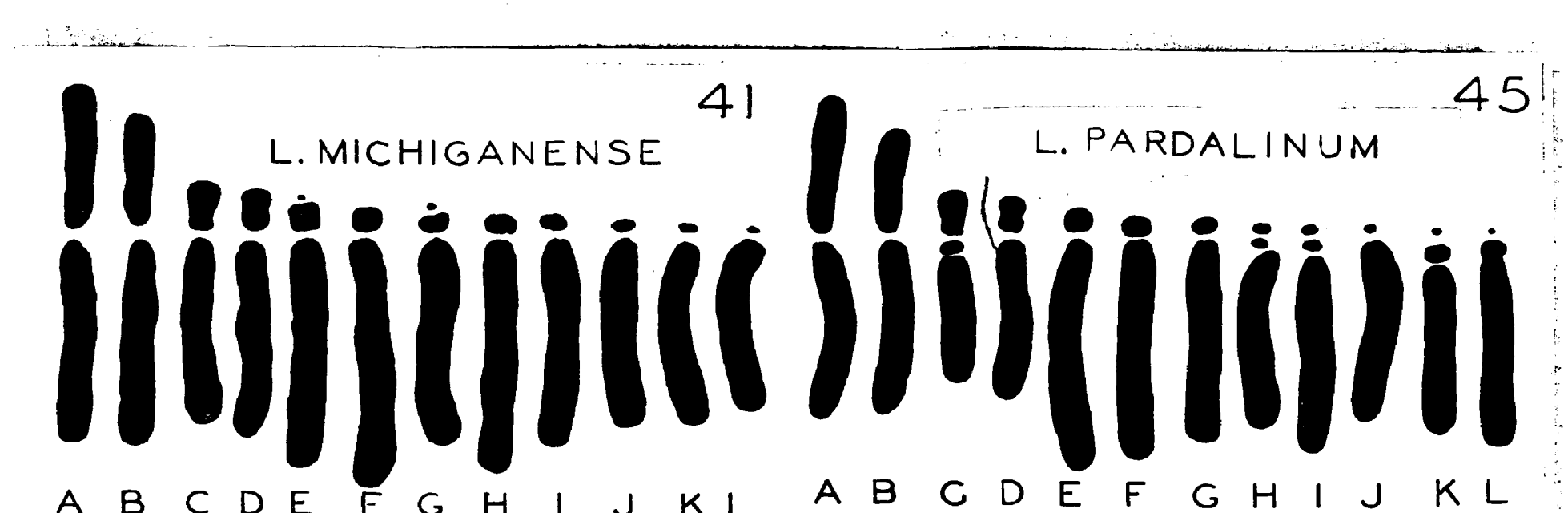

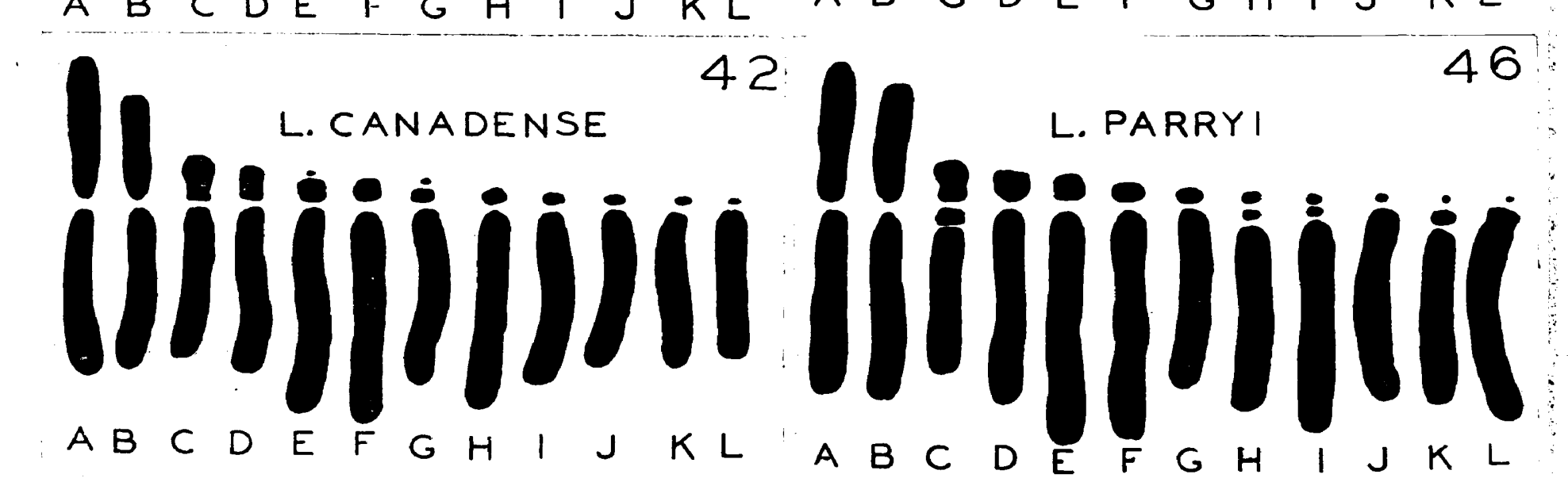

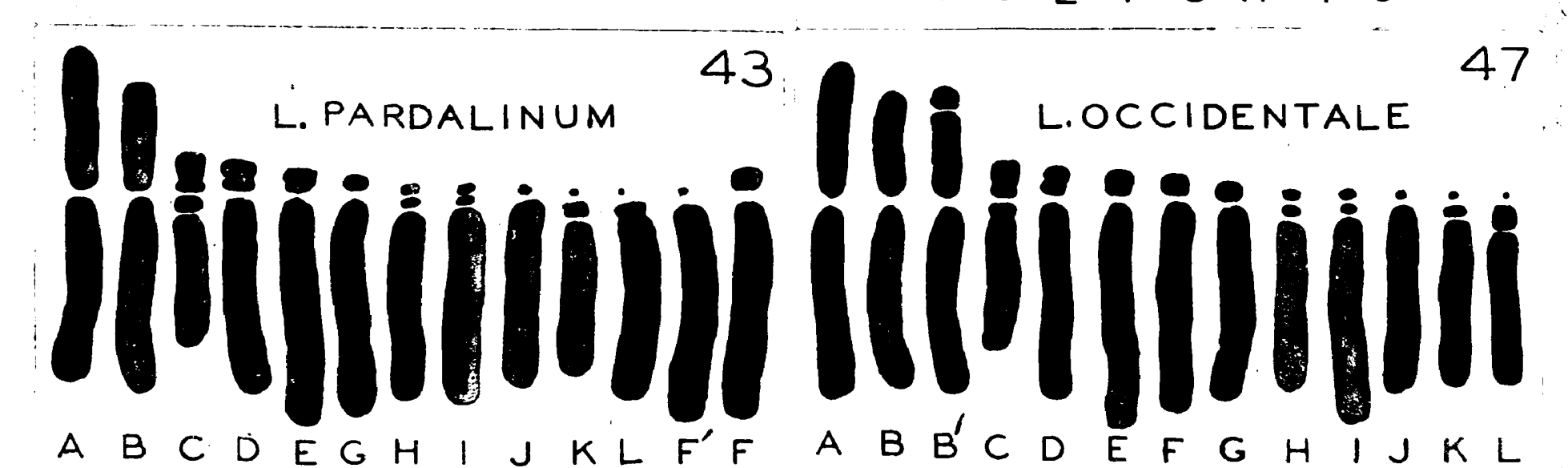

Hiiijiij)ir ibijijiijiliij 